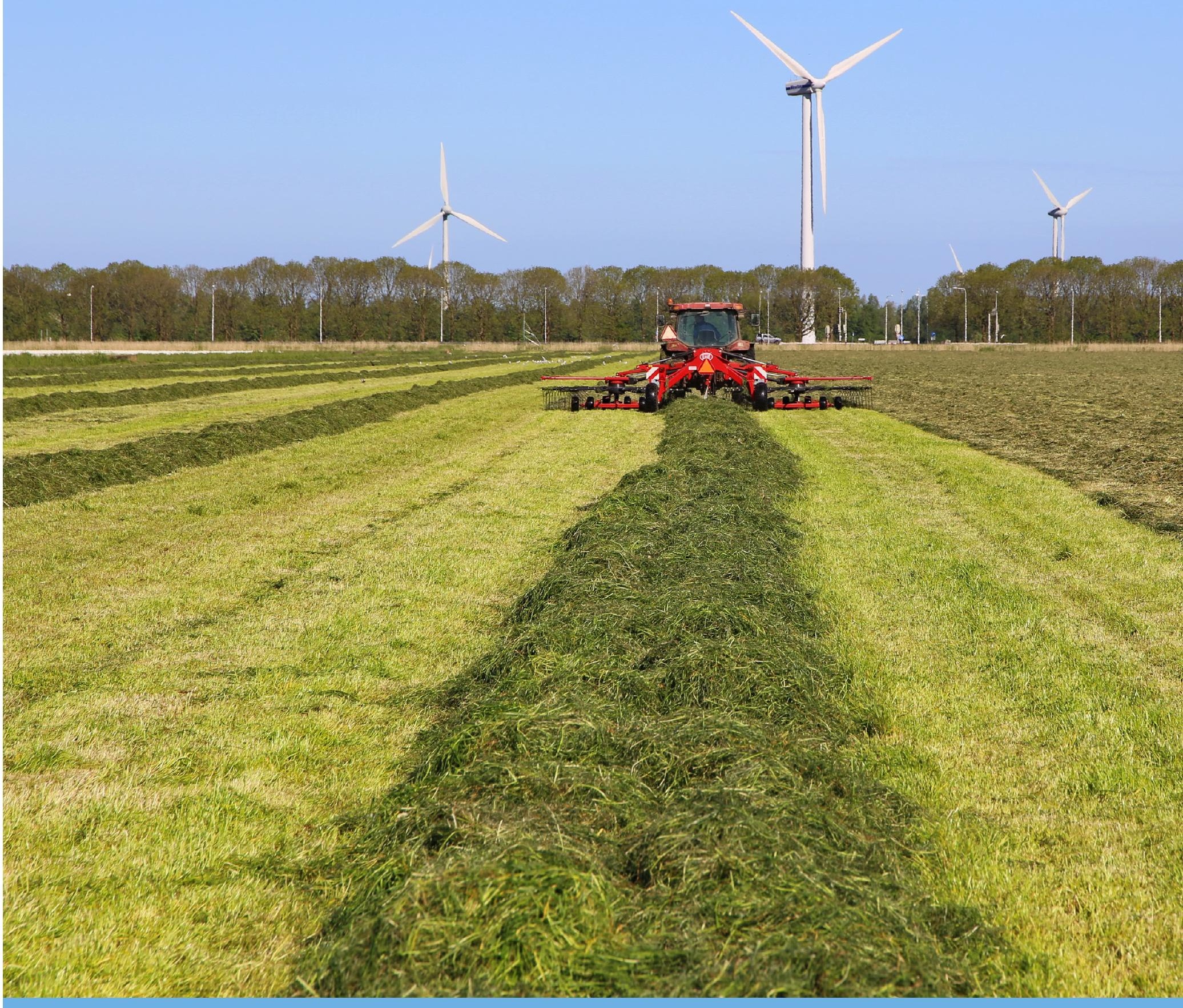

\title{
Grasdrogen (een energiedienst en meer eiwit van eigen land)
}





\section{Grasdrogen (een energiedienst en meer eiwit van eigen land)}

Paria Sefeedpari, Luuk Gollenbeek, Gerard Migchels

Wageningen University \& Research

Dit onderzoek is uitgevoerd door Wageningen Livestock Research en is een product van Landbouw als vliegwiel voor de energietransitie (AF 17013) project, een samenwerking tussen LTO Noord, Alliander, Stedin, Windunie, Petawatts, Wageningen University \& Research en ECN-TNO. Deze PPS ontvangt financiële steun van de Topsector Agri \& food.

Wageningen Livestock Research

Wageningen, oktober 2021

Openbaar

Rapport 1341 
Sefeedpari, P., L. Gollenbeek, Migchels G., 2021. Grasdrogen (een energiedienst en meer eiwit van eigen land). Wageningen Livestock Research, Openbaar Rapport 1341.

Samenvatting NL In Nederland wordt veel gras geproduceerd en gedroogd met fossiele brandstoffen zoals steenkool. Het doel van een fossielvrije toekomst met energietransitie kan worden gerealiseerd, terwijl de belangstelling voor zelfgekweekte voerbronnen in de veehouderij toeneemt. In dit rapport worden de factoren die van invloed zijn op de kwaliteit van gras en verliezen, energieproblematiek, $\mathrm{CO}_{2}$-footprint en de mogelijkheden van grasdrogen op twee niveaus besproken: i) bedrijfsschaal (decentraal) en ii) regionale schaal (gecentraliseerd). Er worden conclusies getrokken over toekomstige grasdrogers op groene energie.

Summary UK A large amount of grass is produced in the Netherlands and is dried using fossil fuels such as coal. The goal of a fossil-free future with energy transition can be realized, while interest in home-grown feed sources in livestock farming is increasing. In this report, the factors affecting quality of grass and losses, energy issues, $\mathrm{CO}_{2}$-footprint and the possibilities of grass drying are discussed at two levels: i) farm scale (decentralised) and ii) regional scale (centralised). Conclusions are drawn about future gras dryers running on green energy.

Dit rapport is gratis te downloaden op https://doi.org/10.18174/556287 of op www.wur.nl/livestock-research (onder Wageningen Livestock Research publicaties).

\section{(cc))BY-NC}

Dit werk valt onder een Creative Commons Naamsvermelding-Niet Commercieel 4.0 Internationaallicentie.

(C) Wageningen Livestock Research, onderdeel van Stichting Wageningen Research, 2021

De gebruiker mag het werk kopiëren, verspreiden en doorgeven en afgeleide werken maken. Materiaal van derden waarvan in het werk gebruik is gemaakt en waarop intellectuele eigendomsrechten berusten, mogen niet zonder voorafgaande toestemming van derden gebruikt worden. De gebruiker dient bij het werk de door de maker of de licentiegever aangegeven naam te vermelden, maar niet zodanig dat de indruk gewekt wordt dat zij daarmee instemmen met het werk van de gebruiker of het gebruik van het werk. De gebruiker mag het werk niet voor commerciële doeleinden gebruiken.

Wageningen Livestock Research aanvaardt geen aansprakelijkheid voor eventuele schade voortvloeiend uit het gebruik van de resultaten van dit onderzoek of de toepassing van de adviezen.

Wageningen Livestock Research is NEN-EN-ISO 9001:2015 gecertificeerd.

Op al onze onderzoeksopdrachten zijn de Algemene Voorwaarden van de Animal Sciences Group van toepassing. Deze zijn gedeponeerd bij de Arrondissementsrechtbank Zwolle. 


\section{Inhoud}

Woord vooraf $\quad 5$

$\begin{array}{ll}\text { Samenvatting } & 7\end{array}$

$\begin{array}{llr}1 & \text { Inleiding } & 9\end{array}$

1.1 Motief en probleemstelling 9

$\begin{array}{lll}1.2 \text { Doel } & 10\end{array}$

$\begin{array}{lll}1.3 \text { Aanpak } & 10\end{array}$

$2 \quad$ Grasdrogen techniek $r$

$\begin{array}{lll}2.1 & \text { Achtergrond van het drogen van gras } & 11\end{array}$

2.2 Opties en type drogers 12

2.2.1 Trommeldroger 12

2.2.2 Banddroger 12

2.2.3 Statisch grasdrogen (ronde balen drogen) 13

2.2.4 Hooibak met warmtebeluchter 14

$\begin{array}{lll}2.3 & \text { Energievoorziening voor grasdrogers } & 14\end{array}$

$\begin{array}{llr}3 & \text { Verliezen en kwaliteit van gras } & 17\end{array}$

$\begin{array}{lll}3.1 & \text { Veld- en procesverliezen } & 17\end{array}$

3.1.1 Maaimoment impact op grasdrogen 18

$\begin{array}{lll}3.2 & \text { Gedroogd gras kwaliteit } & 18\end{array}$

3.2.1 Opname grasbrok en effect grasdrogen op kwaliteit en benutting
van het eiwit

3.2.2 Grasbrok versus ingekuild gras $\quad 19$

3.2.3 Verteerbaarheid: een belangrijke factor $\quad 20$

$\begin{array}{lll}3.3 & \text { Eiwit van eigen land } & 20\end{array}$

$\begin{array}{lll}3.4 & \text { Minder afhankelijkheid van krachtvoer } & 21\end{array}$

$4 \mathrm{CO}_{2}$-footprint en energieverbruik van grasdrogen $\quad 23$

4.1 Scenarioberekeningen voor fossiele brandstof en groene stroom 23

$\begin{array}{lll}4.2 & \text { Stroomverbruik } & 29\end{array}$

$\begin{array}{lll}4.3 & \text { Effect minder krachtvoerverbruik } & 30\end{array}$

$5 \quad$ Discussie en conclusie $\quad 31$

5.1 Verliezen en Impact kunstmatige grasdroging op voerkwaliteit 31

$\begin{array}{lll}5.2 & \text { Impact op } \mathrm{CO}_{2} \text {-footprint } & 31\end{array}$

5.3 Uitdagingen voor toekomstige grasdrogers met zonne-elektriciteit 32

$\begin{array}{ll}\text { Literatuur } & 33\end{array}$

Bijlage 1 Aannames voor het berekenen van $\mathrm{CO}_{2}$-footprint 34

Bijlage 2 Resultaten van $\mathrm{CO}_{2}$-footprint $\quad 35$ 
- 


\section{Woord vooraf}

Het doel van de PPS Landbouw als vliegwiel voor de energietransitie is om invulling te geven aan de rol van de landbouw in de energietransitie. Dit door het maximaliseren van de bijdrage van de landbouw op een wijze waarbij hernieuwbare energieproductie en -consumptie een integraal rendabel onderdeel van het agrarische bedrijf wordt. Voor een aantal representatieve bedrijfssystemen met veel grondgebruik (akkerbouw en melkveehouderij) wordt het energieverbruik in kaart gebracht. De modelgegevens bieden partijen inzicht in het energieverbruik in regionale energienetwerken. Door regionale spreiding van bedrijfstypen geeft dit project onderdeel input voor andere onderdelen van het project.

De melkveehouderij staat voor grote uitdagingen. Meer eigen eiwit, minder ammoniak- en methaanemissies en bijdragen aan meer biodiversiteit krijgen meer aandacht. Tegelijkertijd is het voor melkveehouders ook een uitdaging om maximaal bij te dragen aan de energietransitie, door niet alleen duurzame energie te produceren, maar ook energiediensten te leveren die bijdragen aan netstabiliteit. Dit rapport brengt in kaart wat de meerwaarde van grasdrogen kan zijn en beoordeelt de technische mogelijkheden voor grasdroogsystemen, energieverbruik en $\mathrm{CO}_{2}$-footprint met verschillende energiebronnen (o.a. kolen, grijze stroom, groene stroom en restwarmte).

Het voorliggende onderzoek is uitgevoerd door Wageningen Livestock Research. De auteurs danken de financiers voor hun deskundige begeleiding van het onderzoek. Die dank geldt ook Theun Vellinga en Mai Timmerman, voor het $\mathrm{CO}_{2}$-footprint deel van het rapport en alle mensen en personen die in het kader van deze studie zijn geconsulteerd.

Namens het onderzoeksteam,

Gerard Migchels, projectleider 


\section{Samenvatting}

De afgelopen jaren is in Nederland de aandacht voor de melkveehouderij en de energiesector toegenomen om oplossingen te vinden voor een fossielvrije productie, terwijl de kwaliteit van melk wordt verhoogd en de negatieve milieueffecten worden verminderd. Door gebruik te maken van nieuwe droogtechnieken in combinatie met geëlektrificeerde werking, is er potentieel om de verbranding van steenkool aanzienlijk te verminderen of te vervangen, terwijl er meer eiwit van eigen land worden geproduceerd.

In het vorige onderzoek (Visser et al., 2020) zijn mogelijkheden onderzocht om een groot deel van de zelfgeproduceerde hernieuwbare energie te benutten in de bedrijfsvoering. Uit dit onderzoek bleek dat door meer eigen energie te gebruiken (voornamelijk tijdens piek-productie uren), er meer zonnepanelen kunnen worden geplaatst binnen de bestaande netaansluiting. Dit kan extra inkomsten opleveren bijvoorbeeld door machines en processen, die nu diesel als brandstof gebruiken, te elektrificeren. Dit leidt tot vermindering van de $\mathrm{CO}_{2}$-uitstoot van het bedrijf (of de keten) en uiteindelijk tot een duurzamere bedrijfsvoering. Op deze manier kunnen melkveehouderijbedrijven een driedubbele bijdrage leveren aan de energietransitie: hogere hernieuwbare energieproductie, verbeterde netstabiliteit en verlaging van de maatschappelijke kosten.

Grasdrogen met groene energiebronnen zoals zonne- en windenergie is een van de mogelijke manieren om de eigen geproduceerde hernieuwbare energie te gebruiken binnen de veehouderij met grasland(Visser et al., 2020). Een uitdaging hierbij is om de energievraag zodanig in evenwicht te brengen dat het lokale LS-net tijdens piekuren niet wordt overbelast en er hierdoor efficiënter kan worden opgewekt en gebruikt. Eén van de oplossingen is elektrificatie van grasdrogers op een centrale groepsbedrijven of op bedrijfsschaal. Bovendien is het toevoegen van dergelijke techniek financieel en milieutechnisch aantrekkelijk, omdat ze ergens in de keten energie kunnen besparen. Het drogen van gras resulteert bijvoorbeeld in minder gebruik van fossiele brandstoffen en/of bij uitvoering op de boerderij kan het leiden tot minder transport.

Dit rapport brengt de technische mogelijkheden voor grasdroogsystemen, energieverbruik en $\mathrm{CO}_{2}-$ footprint bij het drogen van gras met verschillende energiebronnen (zoals kolen, grijze stroom, groene stroom en restwarmte) in kaart. Dus mogelijke opties moeten verder worden onderzocht om de beste selectie op verschillende schalen te maken.

Om grasdrogers te ontwikkelen en te ontwerpen, die passen bij de huidige situatie op regionale schaal of op bedrijfsschaal, worden de volgende kernboodschappen van deze notitie overwogen:

- Bij kunstmatig gedroogd gras treedt ongeveer 10-15\% minder droge stof verlies op.

- Bij kunstmatig gedroogd gras treedt ongeveer 10-30\% minder VEM-verlies op.

- Maaimoment wordt binnen grenzen van droging flexibeler. Technologie kan dit flexibeler maken om drogers te voeden met batches op boerderijschaal.

- Door het gedroogde gras te verwerken tot grasbrokjes en te voeden met andere voedersoorten zoals luzerne, kan het worden ingezet als 1 op 1 vervanger voor krachtvoer, mits de voedingswaarde overeenkomt.

- De berekende gemiddelde $\mathrm{CO}_{2}$-footprint bij reguliere centrale droging is hoger dan voor regulier mengvoer. Berekende gemiddelde footprint uitgaande van elektrificatie en groenstroomverbruik leidt tot een lagere gemiddelde $\mathrm{CO}_{2}$-footprint voor centrale grasdroging t.o.v. mengvoer.

- Grasdroging op boerderijschaal leidt tot een verlaging van de gemiddelde $\mathrm{CO}_{2}$-footprint ten opzichte van mengvoer, zowel bij het gebruik van grijze stroom als groene stroom.

- Voordrogen op boerderijschaal draagt bij aan een lagere $\mathrm{CO}_{2}$-footprint per $\mathrm{kg}$ ds gras, en met goed management en technieken kan dit proces ook nog worden verkort. Plannen om meer energie te winnen uit hernieuwbare bronnen en het drogen van gras in de spits, zijn veelbelovende oplossingen. Verder onderzoek is nodig om de mogelijkheden te verkennen. 
- Drogen met hogere temperatuur, laagwaardige warmte (restwarmte) en drogen in een hooibak zijn aan te raden grasdroogtechnieken.

Om grasdrogen in te kunnen zetten voor netstabiliteit zal verder onderzoek nodig zijn op de volgende vlakken:

- Techniek grasdrogen

- In de huidige notitie zijn berekeningen gedaan op basis van aannames. Onbekend is nog of en hoe elektrificatie van het proces kan plaatsvinden.

- De manier van elektrificeren kan ook effect hebben op de inzetbaarheid van de grasdrogerij voor netstabiliteit.

- Er moet een grasdroger worden ontwikkeld op kleinschalige exploitatie met hoge temperatuur en korte verblijftijd (bijvoorbeeld een banddroger met hoge temperatuur en korte drogenperiode). Op grote schaal kan de transitie naar groene energie op korte termijn worden gerealiseerd.

- Inrichten van de keten

- Op welke manier dienen energieproductie en -consumptie op elkaar afgestemd te worden?

- Wat betekent dit voor de inrichting van de grasdrogerij (welke techniek, centraal decentraal etc.)?

- Wat betekent dit voor het boerderijmanagement (bijvoorbeeld maaimoment, bemesting, rantsoensamenstelling, alle gras tot brok)?

- Voederwaarde

- Er is nu vooral informatie beschikbaar over voederkwaliteit van gras gedroogd bij centrale drogerijen. Drogerijen op boerderijschaal zijn juist nu in opkomst, wat onderzoek van dergelijk gedroogd gras (al dan niet als brok) vraagt.

- Geconcludeerd wordt dat voor het drogen hoogwaardig gras moet worden gebruikt. Wat is de gewenste kwaliteit en hoe wordt deze bereikt? 


\section{$1 \quad$ Inleiding}

\subsection{Motief en probleemstelling}

Energie is een essentiële motor voor vooruitgang in de landbouw. Technische vooruitgang en economische ontwikkeling bij het aanpakken van milieuproblemen vormen de één van de grote uitdagingen van onze tijd. De transitie naar een fossielvrije toekomst is één van de ambities die binnen een relatief korte termijn gehaald moet worden. Echter, deze overgang naar een fossielvrije toekomst kan een complex proces zijn, als het niet goed wordt beheerd. Het introduceren van alternatieven zal veel tijd vergen, terwijl een duurzame investering kan leiden tot een onzekere economische haalbaarheid. Deze ambities moeten in korte tijd worden gerealiseerd om aan de stijgende wereldwijde energievraag te voldoen. Op basis van de EU-routekaart worden gezamenlijke acties gecategoriseerd en geprioriteerd in zeven hoofdstrategieën als bouwstenen van een net-zero economie:

1. Optimaal gebruikmaken van de voordelen van energie-efficiëntie, met inbegrip van energieneutraal bouwen;

2. De inzet van hernieuwbare energiebronnen en het gebruik van elektriciteit optimaliseren om de energievoorziening van Europa geheel koolstofvrij te maken;

3. Omarmen van schone, veilige en geconnecteerde mobiliteit;

4. Een concurrerende Europese industrie en de circulaire economie als een cruciale randvoorwaarde voor het terugdringen van broeikasgasemissies;

5. Een adequate slimme netwerkinfrastructuur en onderlinge verbindingen ontwikkelen;

6. De voordelen van de bio-economie ten volle benutten en essentiële koolstofputten creëren;

7. De resterende $\mathrm{CO}_{2}$-emissies aanpakken door middel van koolstofafvang en -opslag.

Om de doelstellingen voor de energietransitie van veehouderij op korte termijn te halen, is een integrale aanpak en een consistent beleid vereist. Dit is ook belangrijk omdat investeringen in gebouwen op veehouderijbedrijven lange termijn investeringen zijn. Flexibiliteit en betaalbaarheid van de technologieën voor alle boeren zijn cruciaal om deze modernisering te implementeren.

Het grootste deel van de vraag naar energie vanuit de landbouw en de veehouderij zal in de toekomst ingevuld moeten worden met hernieuwbare energie (zoals zonne-energie of windenergie). Daarnaast zou de extra opgewekte energie een bron kunnen zijn voor de energievraag elders. Deze ambitie stuitte echter al op problemen, bijvoorbeeld beperkingen van de bestaande infrastructuur. Vooral op het platteland is de bestaande netinfrastructuur beperkt, omdat deze niet is gebouwd om (op een laag niveau in het elektriciteitsnet) grote hoeveelheden elektriciteit terug te geven aan het net (Visser et al., 2020). Dit probleem ontstaat door (de te lage capaciteit van het elektriciteitsnet in de piekuren van de energieproductie) kan een barrière vormen, vooral in combinatie met een hoge ambitie om zonnepanelen te realiseren op het boerenerf. Bovendien, met beperkingen in de ontwikkeling van het bestaande net en om de energietransitie in stand te houden met behoud van de energiezekerheid, is het cruciaal om te zoeken naar manieren om de overtollige/overschot energie te benutten. Waardoor binnen de capaciteit van het huidige elektriciteitsnet fors meer zonnepanelen kunnen worden geplaatst door elektrificatie van operaties.

In een recent onderzoek in Nederland is een aantal mogelijkheden onderzocht om de energievraag zodanig in evenwicht te brengen dat tijdens piekuren het lokale laag- en middenspanningsnet (LS\&MS-net) niet wordt overbelast, waardoor meer groene stroom worden opgewekt en efficiënter worden gebruikt. Eén van de oplossingen is om de overtollige groene stroom in te zetten in extra processen die nuttig zijn voor veehouderij, bijvoorbeeld het drogen van gras. Bovendien kan het toevoegen van dergelijke processen financieel aantrekkelijk en milieuvriendelijk zijn (bijvoorbeeld door besparing op transportkosten, minder gebruik van fossiele brandstoffen). In het geval van grasdrogen is de totale energiebehoefte, en dus het succes van de overtollige/overschot stroom inzet, afhankelijk van het beheer van het proces. Ter illustratie, volgens Visser et al. (2020) vereist grasdroging van voorgedroogd gras ongeveer $25 \mathrm{~kW}$, maar met vers drogen kan de stroombehoefte oplopen tot 800 
kW. Dus het vermogen om gras te drogen (op boerderij- of regionale schaal) is een andere bepalende factor bij het selecteren van de geschikte technologie.

Grasdrogen is ook een manier om het eiwit van eigen land te verhogen. Dit maakt de landbouw duurzamer, omdat de inputbronnen kunnen worden geoptimaliseerd, bijvoorbeeld de stikstofaanvoer. Daarom drogen steeds meer melkveehouders hun gras om het als voer te gebruiken en daarmee de aankoop van krachtvoer te beperken. Voor een biologische boer is het ook erg interessant om groenvoer van het eigen bedrijf te laten drogen, omdat biologisch krachtvoer erg duur is. Bij de reguliere manier van grasoogsten treedt op het veld een verlies op en een deel van het in gras aanwezige eiwit breekt af door de enzymen of door microbiële enzymen tijdens het inkuilen. Een succesvolle grasdroging is een eerste stap voor de melkveehouderij om de kwaliteit van het ruwvoer zo hoog mogelijk te houden.

Dit rapport is een weergave van de mogelijkheden van het drogen van gras met behulp van groene energie op twee schalen. De potentie van dit ontwerpproces, de uitwerking van de verschillende opties en hun $\mathrm{CO}_{2}$-footprint die daarin naar voren zijn gekomen. Het rapport is bedoeld als inspiratiebron voor ondernemers en/of adviseurs die geïnteresseerd zijn in het zoveel mogelijk benutten van zelf geproduceerde energie en grasvoer in de eigen bedrijfsvoering.

\subsection{Doel}

Het doel van dit project is om inzicht te krijgen in de voor- en nadelen van grasdroging, verschillende technieken (een centrale grasdroger of een droger op boerderijschaal) en uiteindelijk de bijdrage van verschillende grasdroogtechnieken aan de $\mathrm{CO}_{2}$ footprint.

De volgende onderzoeksvragen zijn geformuleerd:

- Bij grasdrogen in het veld zijn er verliezen, in hoeverre kunnen de onvermijdelijke verliezen tijdens het drogen van gras op het veld worden voorkomen door het gras te drogen in een (elektrische) grasdrogerij?

- Grasdrogen op hogere temperaturen in een grasdrogerij heeft invloed op de kwaliteit van het eiwit en daarmee ook invloed op benutting van het eiwit door de koe. Hoe groot is dit effect? Wat zijn de mogelijkheden om krachtvoer te vervangen? En wat betekent dit voor het aandeel eiwit van eigen land?

- Wat is het effect van grasdrogen op de carbon footprint?

In dit rapport bespreken we specifiek de factoren die van invloed zijn op de kwaliteit van gras en verliezen, energie en $\mathrm{CO}_{2}$-footprint kwesties van kunstmatig grasdrogen op twee niveaus: i) Boerderijschaal (gedecentraliseerd) en ii) Regionale schaal (gecentraliseerd).

\subsection{Aanpak}

Het onderzoek is uitgevoerd door middel van een literatuuronderzoek, informatie is verzameld uit formele artikelen en WUR-rapporten en ook 'grijze' literatuur van internet (tijdschriften / websites) is gebruikt. Eerste verkennende berekeningen over de $\mathrm{CO}_{2}$-footprint van grasdroging zijn gedaan met gegevens uit Ecoinvent en met uitgangspunten zoals benoemd in de in de tekst (zie hoofdstuk 4) . 


\section{Grasdrogen techniek}

\section{$2.1 \quad$ Achtergrond van het drogen van gras}

Het conserveren van gras als voer is een methode om gras te behouden (in kuilvoer, grasbalen en/of grasbrok) en wordt op verschillende manieren uitgevoerd, maar de meest traditionele en eenvoudige methoden zijn gebaseerd op het verminderen van het watergehalte van het gras door middel van drogen. Dit kan op natuurlijke wijze op het land worden gedaan of kunstmatig bij grootschalige installaties ${ }^{1}$. In Nederland is vers gras beschikbaar van april tot oktober, om jaarrond gras te kunnen voeren moet overtollig gras (wanneer gras harder groeit dan de koeien op dat moment kunnen opeten) tijdens het groeiseizoen worden geconserveerd.

Zon- en winddroging in open ruimte is de belangrijkste traditionele methode die wordt gebruikt voor het drogen van gewassen en gras. Deze methode heeft echter zijn beperkingen, zoals grote verliezen na de oogst, veroorzaakt door breuk en bladverlies, onvoldoende drogen, schimmelaanvallen, invasie van insecten, vogels en knaagdieren, onverwachte regen en andere meteorologische verschijnselen. Bovendien vereisen conventionele droogmethoden meer land, tijd en een langere droogperiode. Kunstmatig drogen heeft de afgelopen jaren weer meer aandacht gekregen vanwege het hogere rendement (García-Valladares et al., 2020) en het feit dat de weersomstandigheden minder van invloed zijn op het oogstmoment. Met het Nederlandse weer is velddrogen niet het hele jaar door een optie. De beste manier om het eiwitgehalte van het gras te behouden, is door middel van kunstmatige droging tot hooi.

Grasdrogen kan op verschillende niveaus gebeuren (tabel 2.1). Er zijn momenteel in Nederland grasdrogerijen die regionaal opereren en er wordt op boerderij aan grasdroging gedaan. Een boer kan verschillende redenen hebben om tot grasdroging over te gaan. Het geeft de mogelijkheid om het gras in balen of in pellets voor lange tijd op te slaan zonder dat er grote verliezen optreden. Tevens zijn hooi en grasbrokken marktwaardige producten. Voor het vervangen van krachtvoer dienen pellets gemaakt te worden (verhogen van verteerbaarheid en opnamehoeveelheid).

Tabel 2.1 verschillende huidige manieren van grasdrogen.

\begin{tabular}{|c|c|c|c|c|}
\hline Methode & Eindproduct & Schaalniveau & Principe & Verwachte effecten \\
\hline Droging op land & Hooi of kuil & Boerderij & Zon en wind (2-10 dagen) & Referentiesituatie \\
\hline Geforceerd drogen gras & Hooi & Boerderij & $\begin{array}{l}\text { Zon en wind ( } 1-3 \text { dagen) } \\
\text { Beluchten met warme lucht } \\
20-50^{\circ} \mathrm{C}(2-3 \text { dagen })\end{array}$ & 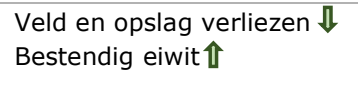 \\
\hline $\begin{array}{l}\text { Hoogwaardige } \\
\text { kunstmatige grasdroging }\end{array}$ & Hooi & $\begin{array}{l}\text { Centrale } \\
\text { grasdrogerij }\end{array}$ & $\begin{array}{l}\text { Beluchten en verwarmen } 100 \text { - } \\
400{ }^{\circ} \mathrm{C}(10 \text { minuten } \\
\text { doorvoertijd) }\end{array}$ & $\begin{array}{l}\text { Veld en opslag verliezen } \downarrow \rrbracket \\
\text { Bestendig eiwit } \mathbb{}\end{array}$ \\
\hline $\begin{array}{l}\text { Hoogwaardige } \\
\text { kunstmatige grasdroging }\end{array}$ & Grasbrok & $\begin{array}{l}\text { Centrale } \\
\text { grasdrogerij }\end{array}$ & $\begin{array}{l}\text { Beluchten en verwarmen } 100 \text { - } \\
400{ }^{\circ} \mathrm{C}(10 \text { minuten } \\
\text { doorvoertijd) }\end{array}$ & 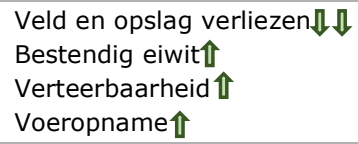 \\
\hline
\end{tabular}

\footnotetext{
${ }^{1}$ Verkrijgbaar bij: http://www.hartog-lucerne.nl/kennisbank/weidebeheer/kuil
} 


\subsection{Opties en type drogers}

Voor een centrale grasdrogerij zijn in principe twee hoofdtypen mechanische grasdrogers: een trommeldroger of een banddroger. Het droogmedium kan zijn: hete gassen, stoom en een meer recente vorm is warmtewisseling (conductie/convectie of indirect/direct) (Loman, 2012). De grasdrogers in Nederland werken voor zover bekend met trommeldrogers. In Nederland zijn voor het lokaal op boerderijschaal grasdrogen een tweetal technologieën bekend, namelijk: statisch drogen of drogen met een hooibak. Mogelijk kunnen een trommeldroger en een banddroger ook op boerderijschaal ingezet worden. Beschrijvingen van deze systemen worden hieronder gegeven.

\subsubsection{Trommeldroger}

De trommeldrogers worden gecategoriseerd als thermische droogsystemen, waarbij het te drogen materiaal door een roterende trommel wordt gevoerd. Materiaal wordt blootgesteld aan een stroom hete lucht terwijl het door een roterende trommel wordt gevoerd. Deze hete lucht kan worden geproduceerd met behulp van een gas- of kolengestookte oven of een oven die wordt verwarmd met een alternatieve brandstof. Gebruik van restwarmte is hierop aan te passen. Zodra het materiaal het vereiste vochtgehalte heeft bereikt, wordt het door de luchtstroom naar de afscheider getransporteerd, die de lucht en het materiaal van elkaar scheidt (cycloon). De capaciteit van de trommel kan - hoewel afhankelijk van de productiecapaciteit - variëren van 3 tot 23 ton waterverdamping per uur en drogen op hoge temperatuur $\left(200-600^{\circ} \mathrm{C}\right.$ ) (Loman, 2012). De grasdrogerijen in Nederland werken meestal met dit type droger. Dit type is inzetbaar als regionale grasdroger en is mogelijk kleinschaliger toepasbaar op de boerderij (Figuur 2.1).

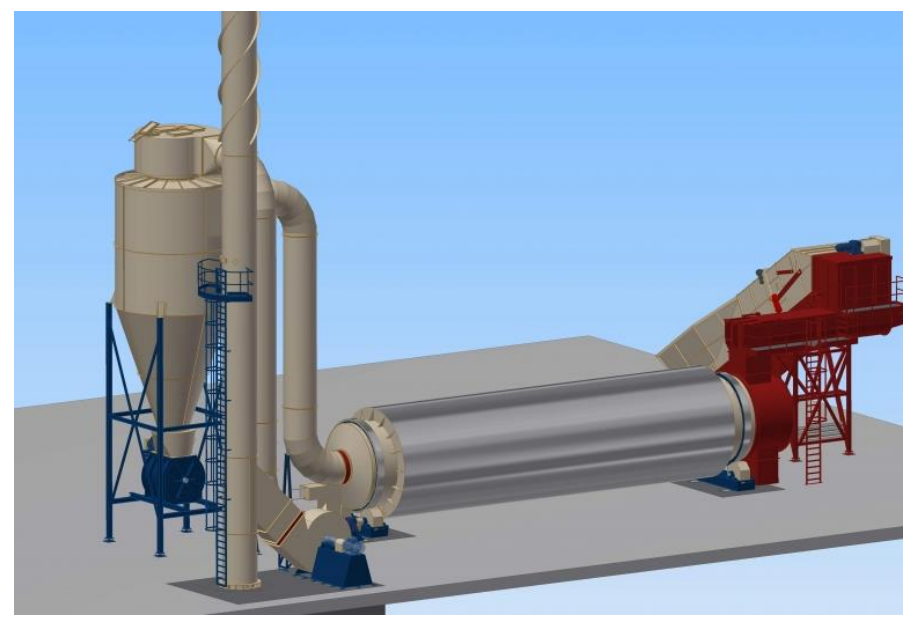

Figuur 2.1 Trommeldroger; Invoer vochtgehalte 25-85\%; Uitgangsvochtgehalte: 10\%; Capaciteit: 20 Ton/uur droog product (Bron: Dutch dryers BV.).

\subsubsection{Banddroger}

De banddroger is de ideale oplossing als het gewenst is om laagwaardige warmte (restwarmte) te gebruiken om een grondstof met een hoog vochtgehalte te drogen en er een bruikbaar droogproduct van te maken. Het droogmedium is droge lucht die kan worden verwarmd door middel van warmtewisselaars.

Bij dit type droger is een stroom hete lucht met een temperatuur van $30-200^{\circ} \mathrm{C}$ al voldoende om een goed droogresultaat te behalen (Loman, 2012). Dit systeem werkt door het te drogen materiaal op een bewegende transportband te transporteren, waarbij hete lucht door het materiaal wordt gezogen om het te drogen. De productiecapaciteit kan variëren van 0,5 tot 40 ton waterverdamping per uur en drogen op lage temperatuur is mogelijk (30-200 ${ }^{\circ} \mathrm{C}$ ) (Loman, 2012). De warme lucht kan geleverd worden door overtollige warmte uit biogasproductie, restwarmte of groene stroom. Momenteel zijn bandgrasdrogers op boerderijniveau die draaien op overtollige warmte uit biogasproductie in ontwikkeling. 
Dit type is inzetbaar als regionale grasdroger en is mogelijk toepasbaar op de boerderij (met laagwaardige warmte en korte droogduur) (Figuur 2.2). De kosten van dit type droger zijn relatief laag ten opzichte van andere types drogers en zijn beter geschikt om te profiteren van de mogelijkheden voor terugwinning van restwarmte, omdat ze bij lagere temperaturen werken (Roos, 2008). Dit type heeft als voordeel dat er niet voorgedroogd hoeft te worden.
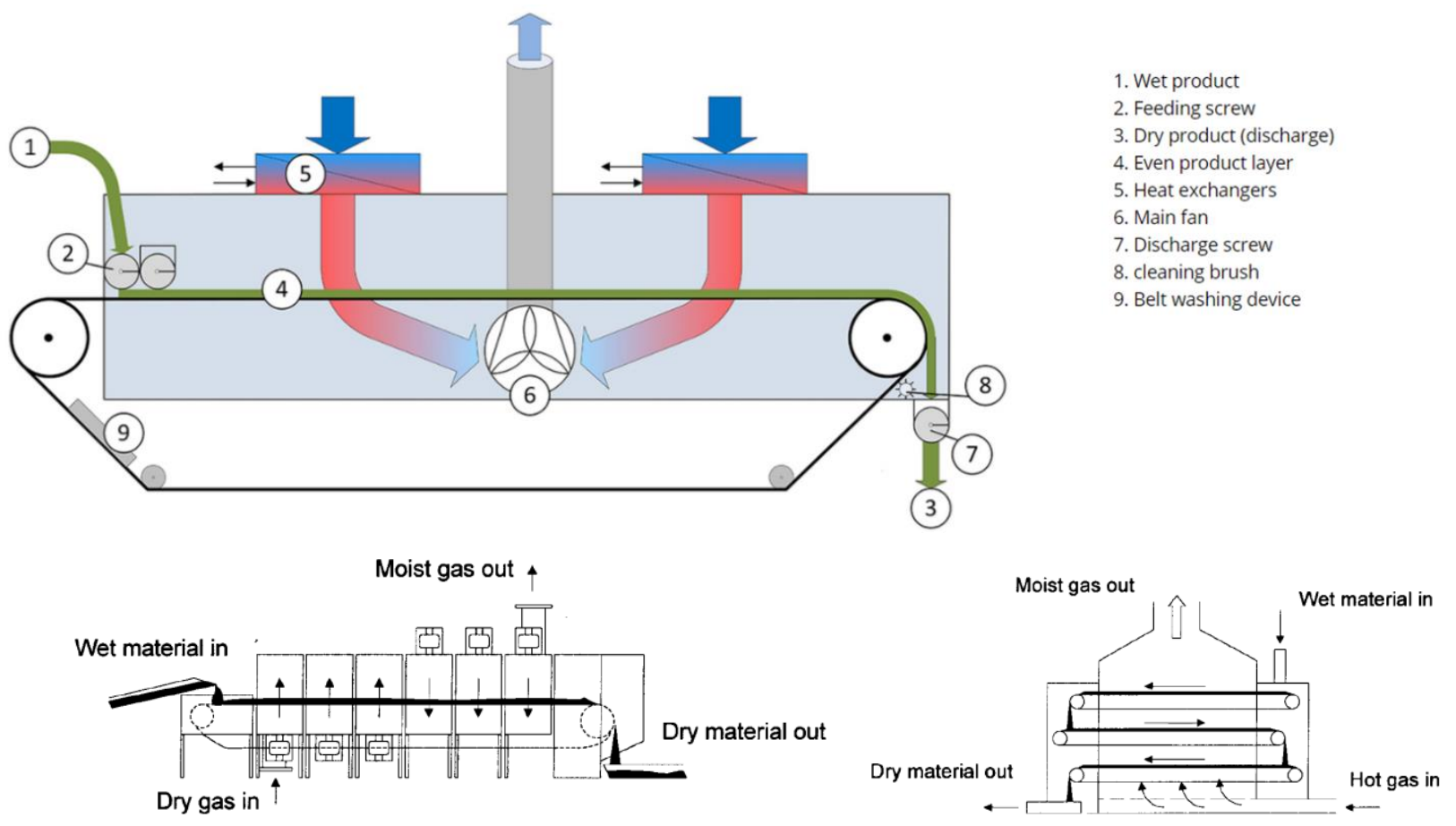

Figuur 2.2 Banddroger (Bron: Rudnick-enners -bovenstaande foto); Brammer and Bridgwater (1999) -onderste foto);.

\subsubsection{Statisch grasdrogen (ronde balen drogen)}

Dit type grasdroger wordt geproduceerd door Lasco-bedrijf in Oostenrijk (Figuur 2.3) en is een type dat wordt gebruikt door een Nederlandse melkveehouder in Hengelo. De informatie uit artikelen, verschenen op nieuweoogst. $\mathrm{nl}$ en lasco.at, is hier gebruikt. Dit systeem bestaat uit een ventilator, een hoofdslang en veel verdeelslangen. Het voorziet de ronde baal van verse drooglucht via flexibele slangen. Voordrogen is een voorwaarde in dit systeem. Dit is een voorbeeld van een grasdroger op de boerderij.

De drooginstallatie in Hengelo droogt met een houtsnipperoven het gemaaide gras in enkele dagen tot hooi. Het systeem bestaat uit een houtsnipperoven, een turbine met pijpen om de lucht te verplaatsen en luchtverdelers om balen te drogen. De turbine blaast tijdens het droogproces lucht door de slangen. Warme lucht van 85 graden uit de oven wordt gemengd met buitenlucht en deze wordt op 40 graden door het gras geblazen. Een andere optie is het plaatsen van een baal op een luchtverdeler met nog een baal erop. Zo kunnen 32 balen per keer binnen 24 tot 36 uur tot hooi worden gedroogd (een middelgroot systeem). Eens in de twaalf uur wordt de oven gevuld met droge houtsnippers. Het drogen kost ongeveer $€ 4,50$ per baal. Met tien tot twaalf balen per hectare komt dit neer op $€$ 50-60 per ha. 

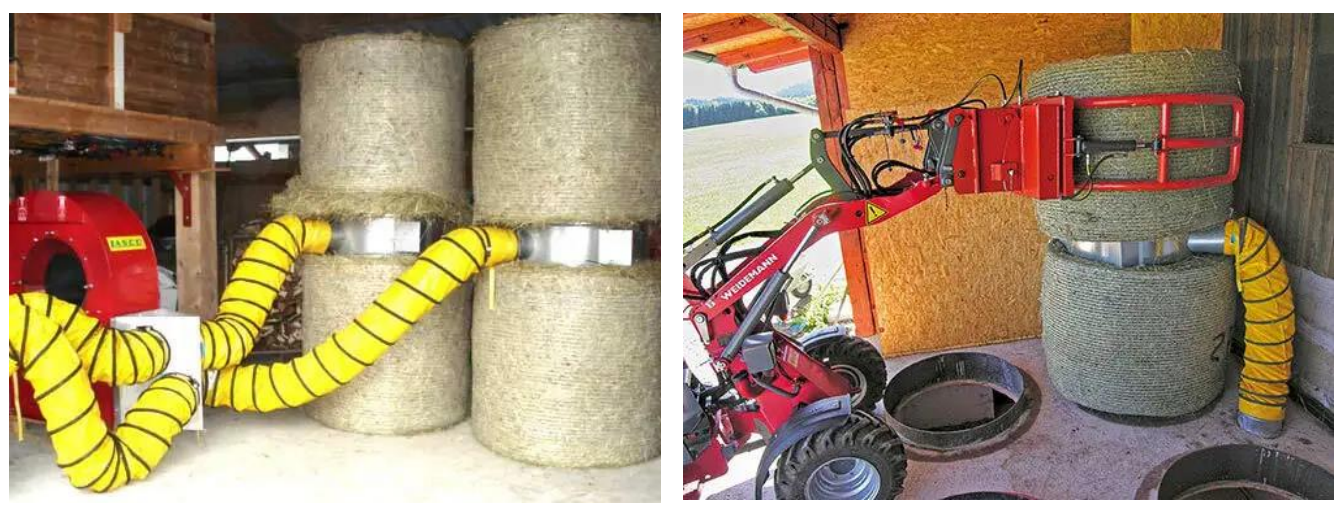

Figuur 2.3 Voorbeeld van ronde balen grasdroger (Bron: lasco.at).

\subsubsection{Hooibak met warmtebeluchter}

Drogen met een hooibak met warmtebeluchter kan door de beperkte droogsnelheid alleen indien het gras op de weide al beperkt voorgedroogd is (Nieuweoogst, 2019) (Figuur 2.4). Om deze optie te realiseren is een apart gebouw nodig $(65 \times 35 \mathrm{~m}$ voor de totale loods uit 43 ha grasland (Melkvee. $\mathrm{nl}$ ). De dakafzuiging voorziet de ventilator van gratis drogende lucht wanneer de zon schijnt. Bij slecht weer of koude seizoenen is naast de dakafzuiging een luchtontvochtiger of een warmtebron nodig. Op de droogzolder van 300 kuub kan het gras van circa 10 hectare gedroogd worden. Na drogen en inklinken, kan de oogst van enkele hectares worden bijgevoegd. In twee tot drie dagen moet het gras 80 procent droge stof bevatten. De totale investering in de installatie bedraagt circa $€ 100.000$ (inclusief de kosten om de ronde balen te drogen). De oven en de grijper opgehangen aan een dakrail kosten respectievelijk 35.000 euro en 25.000 euro (melkvee.nl). Dit drooginstallatie wordt geproduceerd door het Oostenrijkse bedrijf 'Lasco' en er draaien er nu drie van dit systeem in Nederland (Melkvee.nl).
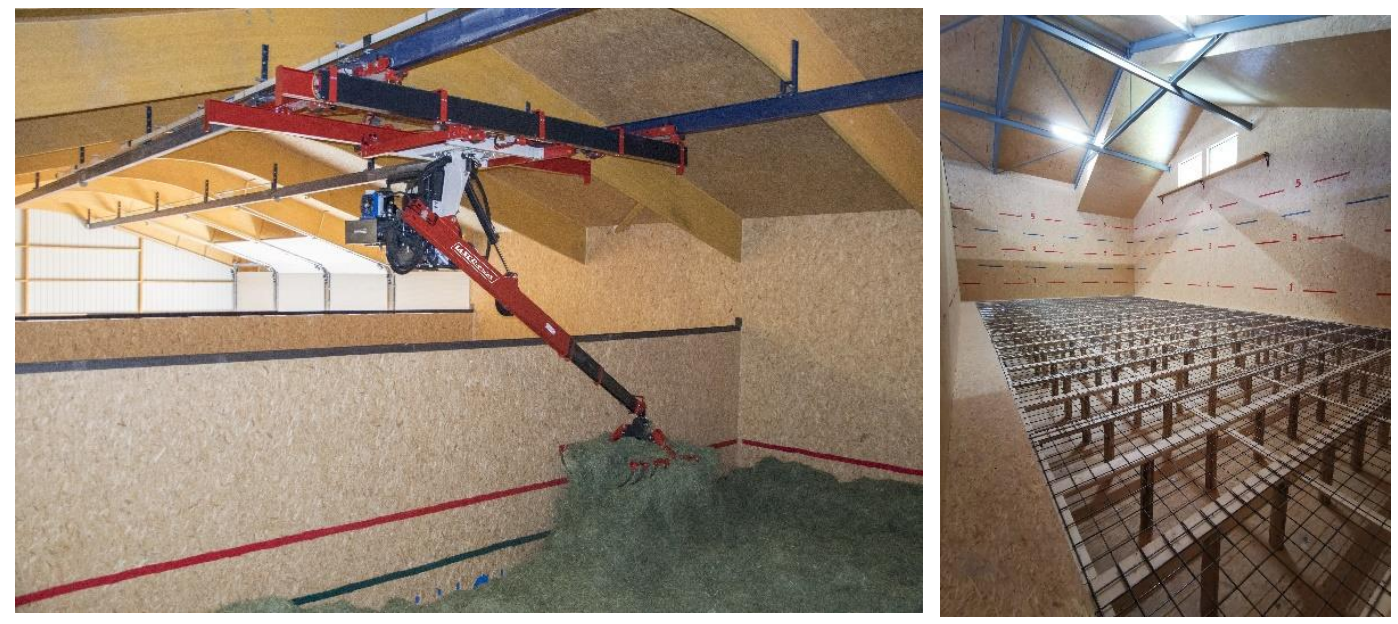

Figuur 2.4 Droogmethode voor hooibakken (Bron: Nieuweoogst, 2019; Lasco.at).

\subsection{Energievoorziening voor grasdrogers}

Het drogen van gras / klaver tot grasbrokken kost veel energie. Het theoretische energieverbruik voor verdamping, uitgaande van een omgevingstemperatuur van $15^{\circ} \mathrm{C}$, ligt in het bereik van 2,48 tot 2,57 GJ/ton verdampt water, afhankelijk van de vochtigheid en temperatuur (Toft, 1998). Daarom kost het maken van grasbrok tien keer zoveel energie per ton droge stof als kuilvoer. Drogen maakt verreweg het grootste deel uit van het totale energieverbruik, namelijk $80 \%$. Voor persen is $10 \%$ van de benodigde energie nodig. Dankzij de huidige subsidie voor het drogen van eiwitrijke voeders is de prijs, van grasbrok, die de boer/afnemer betaalt, lager dan de werkelijke kosten.

De regionale grasdrogers (er zijn in Nederland niet meer dan 10 grasdrogers actief) gebruiken voor hun droogproces fossiele brandstoffen (kolen, diesel, gas). Een paar experimenterende boeren maken 
voor het grasdrogen gebruik van restwarmte en pellet kachels. Een voordeel van het drogen van gras is dat het perceel met minder gras schudden (roeren) minder verliezen kent. Dankzij restwarmte kan de benodigde extra energie duurzaam worden verkregen. Volgens onderzoek in Nederland is restwarmte onder Nederlandse omstandigheden nodig om het gras te drogen (Nieuweoogst, 2019). Nu wordt er ook gebruik gemaakt van de warmte die ontstaat onder het dak (de warmte van de zon overdag). De benodigde warmte kan in de toekomst komen van de warmte die wordt geproduceerd met groene stroom uit zonnepanelen, windmolens of de restwarmte die vrijkomt bij het verwerken van mest of het koelen van mest.

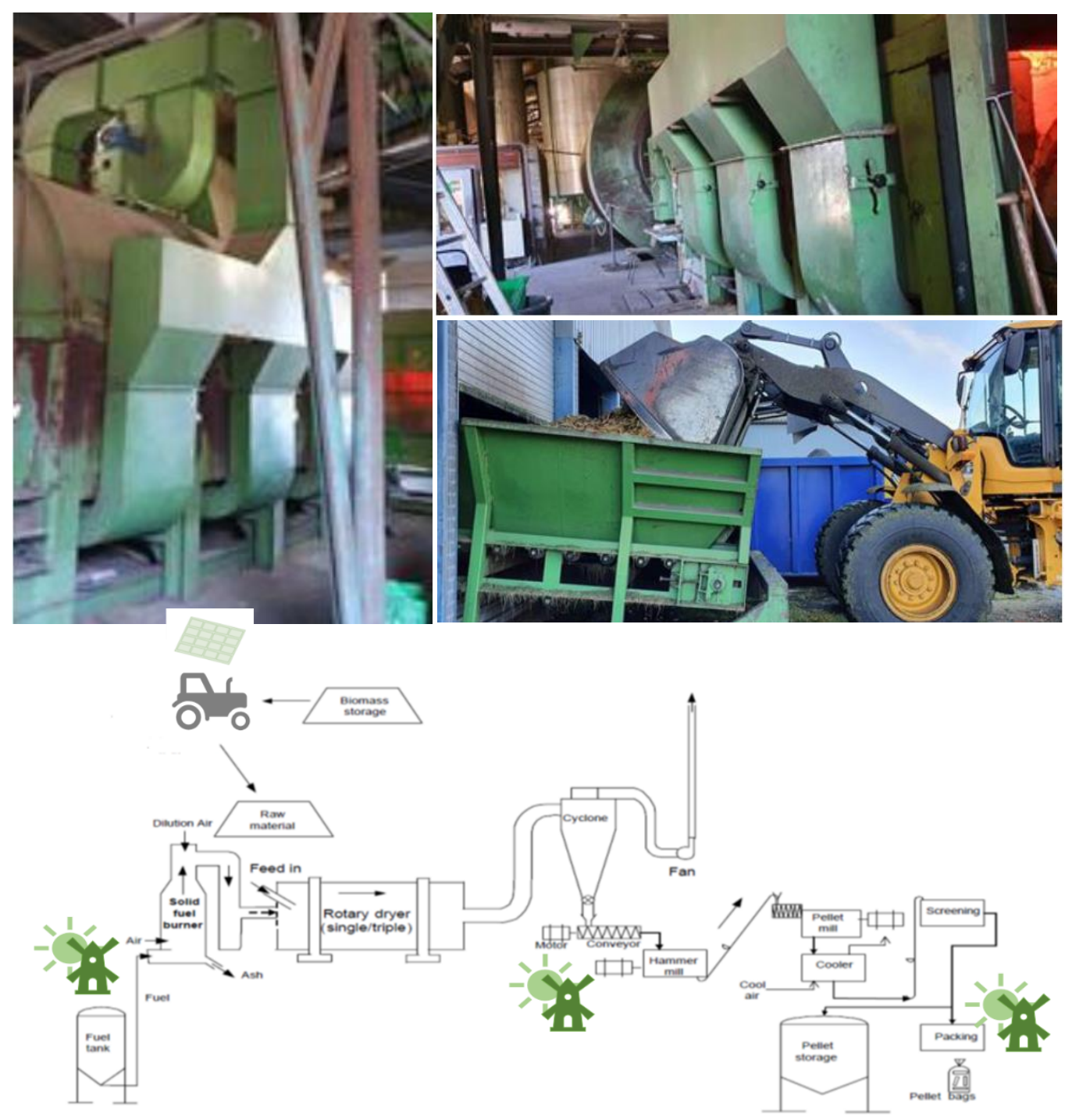

Figuur 2.5 Voorbeeld stroomschema gras drogen op industriële schaal (Bron: Betterwetter.nlbovenstaande foto); aangepast van Mani et al. (2006)- onderste foto). 


\section{Kortom}

Op basis van deze inventarisatie en de overige gerapporteerde bronnen kunnen we de mogelijke technologieën samenvatten in Tabel 2.2. Het vermogen ( $k W$ ) is het geïnstalleerde vermogen. Het geïnstalleerd vermogen van het rondebalensysteem en de hooibak is respectievelijk per eenheid baal en $\mathrm{m}^{2}$ roosteroppervlak.

Tabel 2.2 Opties voor gras drogen op verschillende schalen.

\begin{tabular}{|c|c|c|c|c|c|}
\hline Parameter & Eenheid & Trommeldroger & Banddroger & Ronde balendroger & Hooibak \\
\hline Capacitiet & $t / h$ & $3,0-55$ & gem. 1,5 & gem. $2,0^{*}$ & gem. $3,0^{*}$ \\
\hline Verdampingssnelheid & $t / h$ & $3,0-23$ & $0,5-40$ & gem. $0,5^{*}$ & gem. $0,7^{*}$ \\
\hline Invoer vochtgehalte & $\%$ & $25-85$ & $45-72$ & gem. 40 & gem. 30 \\
\hline Uitgangsvochtgehalte & $\%$ & $10-45$ & $15-25$ & gem. 12 & gem. 6,0 \\
\hline Mogelijke schaal & - & boerderij, centraal & boerderij, centraal & boerderij & boerderij \\
\hline
\end{tabular}

a het geïnstalleerd vermogen: de som van de nominale vermogens van alle stroomverbruikende apparaten in de installatie.

b $0.2 \mathrm{~kW} /$ bale plaats

c $1-2 \mathrm{~kW} / \mathrm{m}^{2}$ rooster oppervlak

d inclusief de kosten van het hooibaksysteem

* geschatte waarde

Bron: Loman (2012); melkvee.nl; lasco.at

Volgende conclusies worden getrokken:

- Banddrogers zijn het meest geschikt voor restwarmte omdat ze op een lagere temperatuur werken dan trommeldrogers. Verder onderzoek is nodig voor deze drogers op boerderij schaal.

- Trommeldrogers kunnen werken bij hogere temperaturen en op grotere schaal. Verder onderzoek is nodig voor trommeldrogers met groene energie en/of op boerderij schaal.

- De huidige trommel- en banddroger zijn relatief duur en vragen veel energie. Door de beperkte droogsnelheid werken de rondebalendroger en hooikist beter wanneer het gras eerst geschud wordt. 


\section{Verliezen en kwaliteit van gras}

\subsection{Veld- en procesverliezen}

In het Handboek Melkveehouderij staat de volgende informatie over de verliezen die optreden bij de voederwinning (Remmelink et al., 2019). Bij de voederwinning kunnen de volgende verliezen optreden:

- Veldverliezen door onder andere ademhaling, uitloging en bewerkingen van het product tijdens het voordrogen op het veld. Juist het meest gunstige diervoeder (blad met hoge verteerbaarheid en voedingswaarde) kan verkruimelen en tussen het gras komen te liggen.

- Gistingsverliezen door omzettingen of afbraak van voedingsstoffen tijdens de conservering tot graskuil.

- Perssapverliezen door het afvloeien van perssap bij het inkuilen van vochtige producten.

- Bewaarverliezen als gevolg van broei, schimmel en rotting door toetreding van lucht en water tijdens de bewaring.

Naast het produceren van hooi op het veld of het maken van kuilgras kan ook gekozen worden voor het kunstmatig drogen van gras. Een realistisch gemiddeld verlies bij het produceren van kunstmatig gedroogd gras is ongeveer $5 \%$ van de droge stof en $8 \%$ VEM. Uitgaande van een korte (minder dan 12 uur) verwelkingsperiode in het veld en een realistisch verlies tussen maaien en voeren met het kunstmatig gedroogde gras (Jannasch et al., 2001; Wilkins, 1976).

De genoemde conserverings- en bewaringsverliezen kunnen onder invloed van allerlei factoren sterk variëren. De gemiddelde verliezen in de praktijk voor kunstmatig en ingekuild gras, bij een goede uitvoering van de graslandwinning staan vermeld in tabel 3.1. Bij ongunstige omstandigheden of minder zorgvuldig werken kunnen de verliezen groter zijn. Kunstmatige droging levert minimaal 5\% verlies aan droge stof op, terwijl dit bij voorgedroogd en ingekuild gras $15-20 \%$ is. VEM-verlies is minimaal $8-10 \%$ voor kunstmatig gedroogd gras en maximaal $40 \%$ voor ingekuild gras. De verliezen (van ds) kunnen ook variëren met het ds-gehalte van het gras, d.w.z. van ongeveer 0,5\% tot 2,5\% verlies voor de gewassen met respectievelijk $20-30 \%$ ds tot $80 \%$ ds-gehalte (Parke et al., 1978; Rotz, 2003).

Tabel 3.1 Gemiddelde verliezen bij conservering en bewaring van kunstmatig gedroogd en ingekuild gras inclusief de verliezen op het veld (Remmelink et al., 2019).

\begin{tabular}{lcc} 
Product & Droge stof (ds) & Verliezen (in \%) \\
\hline Kunstmatig gedroogd* & & VEM \\
\hline in balen geperst & 5 & 8 \\
\hline meel/brok & 5 & 10 \\
\hline Voordroogkuil (35\% ds of meer) & 15 & 20 \\
\hline Vochtige kuil (20 - 35\% ds) & & \\
\hline goed geconserveerd & 15 & 25 \\
\hline matig/slecht geconserveerd & 20 & 40 \\
\hline
\end{tabular}

* Dit is bij centrale grasdroging (dus geen voordroging).

Naast de bovenstaande veldverliezen zijn er ook vervoederingsverliezen. Bij vervoedering treden verliezen op bij het uithalen van het kuilvoer uit de kuil, tijdens het transport naar de stal en door voerresten in de stal. De vervoederingsverliezen zijn sterk afhankelijk van de aard en de kwaliteit van het product. Gemiddeld bedragen de droge stofverliezen bij vervoedering van ruwvoeders 5\%, bij vochtrijke krachtvoeders 3\% en bij droge krachtvoeders 2\% (Remmelink et al., 2019). 


\subsubsection{Maaimoment impact op grasdrogen}

Naast de verliezen tijdens de verwerking van gras tot verschillende vormen, kan het maaimoment ook de kwaliteit van het eindproduct beïnvloeden. Een ander pluspunt van direct drogen na het maaien, is dat het weer minder van invloed is op het maaimoment. Het maaimoment kan daardoor makkelijker ten dienste staan van de maximale gewasopbrengst (VEM, DVE, OEB). Hierbij wordt de kanttekening geplaatst dat bij centrale grasdroging, planning en capaciteit van de installatie erg belangrijk is. Het maaimoment zal hierop ook afgestemd moeten worden.

Daarnaast wordt de kwaliteit van het gewas mede bepaald door de omstandigheden tijdens het maaimoment, bijvoorbeeld de hoeveelheid suikers in het gras (den Boer and Bakker, 2006). Om een reactie (Maillard reactie) te krijgen tijdens het droogproces waarbij onbestendige eiwitten worden omgezet naar bestendige eiwitten zal het suikergehalte voldoende hoog moeten zijn. Daarnaast geven de recente maaimachinetechnieken vermindere verliezen .

Voor het drogen op grote schaal (die nu gangbaar zijn) is geen voordroging op het veld nodig. Maar, op boerderijschaal moet gras worden voorgedroogd op het land (1-3 dagen). Daarnaast blijft het weer een randvoorwaarde voor het kiezen van het maaimoment. Met een grasdroger op boerderijschaal is dit gemakkelijker te beheren dan bij een centrale grasdroger.

\subsection{Gedroogd gras kwaliteit}

\subsubsection{Opname grasbrok en effect grasdrogen op kwaliteit en benutting van het eiwit}

Grasvoer speelt bijna altijd een fundamentele rol in de voeding van koeien. Het hele jaar door voeren van grasproducten - een bron van eiwitten, carotenoïden en vezels - heeft de voorkeur van boeren bij verschillende klimatologische omstandigheden.

In de jaren ' 90 is er op Bosma Zathe onderzoek uitgevoerd naar het vervangen van krachtvoer door grasbrok. De verhouding tussen de Onbestendig Eiwit Balans (OEB) en Darm Verteerbaar Eiwit (DVE) moet in balans zijn. Voor deze DVE: OEB-verhouding geldt een optimum van 9:1 in het rantsoen ${ }^{2}$. Er is gedurende drie stalperioden een rantsoen met grasbrok vergeleken met een krachtvoerrantsoen. Waarbij als uitgangspunt was genomen dat de grasbrok de voerderwaarde van krachtvoer (A-brok: 940 VEM, 95 DVE en 17 OEB) zo dicht mogelijk moest benaderen. De grasbrok was afkomstig van de eerste snede en bevatte gemiddeld 976, 950 en 1003 VEM per kilogram droge stof, DVE en OEB waren gemiddeld 90 en 10 gram per $\mathrm{kg}$ ds. In tabel 3.2 staan de resultaten van gemiddelde voeropname en melkproductiegegevens weergegeven (Boxem, 1992).

Tabel 3.2 Gemiddelde voeropname en melkproductiegegevens (Boxem, 1992).

\begin{tabular}{|c|c|c|c|c|}
\hline \multirow[b]{2}{*}{ Rantsoen } & \multicolumn{2}{|c|}{ Eerste twee seizoenen } & \multicolumn{2}{|c|}{ Laatste seizoen } \\
\hline & $\begin{array}{c}\text { Kuilgras } \\
\text { Krachtvoer }\end{array}$ & $\begin{array}{l}\text { Kuilgras } \\
\text { Krachtvoer } \\
\text { Grasbrok }\end{array}$ & $\begin{array}{c}\text { Kuilgras } \\
\text { Krachtvoer }\end{array}$ & $\begin{array}{c}\text { Kuilgras } \\
\text { Krachtvoer } \\
\text { Grasbrok }\end{array}$ \\
\hline Graskuil* & 10,5 & 10,3 & 11,7 & 10,9 \\
\hline Krachtvoer* & 8,2 & 4,3 & 9,3 & 0,9 \\
\hline Grasbrok* & - & 4,4 & - & 8,5 \\
\hline kVEM & 17,8 & 17,9 & 20,2 & 19,1 \\
\hline DVE (g) & 1.565 & 1.527 & 1.912 & 1.743 \\
\hline OEB (g) & 664 & 639 & 645 & 503 \\
\hline Melk (kg) & 25,5 & 25,6 & 30,8 & 28,7 \\
\hline Vet (\%) & 4,68 & 4,51 & 4,45 & 4,37 \\
\hline
\end{tabular}

*voeropname in $\mathrm{kg}$ ds per koe per dag

\footnotetext{
${ }^{2}$ Verkrijgbaar bij: https://proeftuinveenweiden.nl/nieuws/experiment-beste-maaimoment/a
} 
In de eerste twee seizoenen was de voeropname van het rantsoen met grasbrok vrij goed en verschilde weinig van het rantsoen met krachtvoer. Wel was het melkvetgehalte bij het rantsoen met de grasbrok lager. Uit onderzoek van het IVVO waarbij 40\% van de krachtvoergift was vervangen door grasbrok werd ook een daling in het vetgehalte geconstateerd. Bij een grotere vervanging door grasbrok tijdens het laatste seizoen werd een lagere melkproductie gevonden, welke in overeenstemming was met de lagere energieopname. Voedertechnisch, maar ook uit oogpunt van productie, is het mogelijk bijna alle krachtvoer te vervangen door grasbrok. Dit is mogelijk door meer voedingswaarde uit eigen land te halen, door de energie en eiwitten van het geconserveerde gras optimaal te benutten in combinatie met vers gras, zodat koeien geen krachtvoer nodig hebben om dezelfde voedingsstoffen binnen te krijgen. De voederwaarde mag echter niet of slechts weinig verschillen van die van krachtvoer. Het is dus zaak om bij de winning van grasbrok rekening te houden met het kwaliteitsaspect. Grasbrok in het rantsoen betekent wel dat er extra gelet moet worden op de mineralenvoorziening (Boxem, 1992).

Op de proefboerderijen Bosma Zathe, Heino en Zegveld is in 1991/1992 tevens een vergelijkingsonderzoek tussen grasbrok en luzernebrok gedaan bij vrouwelijk jongvee (Boxem, 1993). De gebruikte grasbrok was van goede kwaliteit. De OEB, lag in vergelijking met graskuil, in alle gevallen op een vrij laag niveau. Dit is inherent aan het drogen van gras, waardoor het eiwit bestendiger wordt en de OEB daalt. De gemeten gemiddelde groei bij het stro-grasbrok-rantsoen lag iets hoger dan de berekende groei op grond van de gemiddeld opgenomen hoeveelheid energie. Met luzernebrok verschilde de berekende en werkelijk gemeten groei nauwelijks. De vastgestelde voederwaarde van de gras- en luzernebrok was in overeenstemming met wat van beide broksoorten verwacht mocht worden (Boxem, 1993).

Het drogen, malen en persen van gras of grasklaver heeft gevolgen voor de structuur van het voedermiddel en daarmee ook voor de eigenschappen die gerelateerd zijn aan voeropname en verteerbaarheid. Grasbrok had in het uitgevoerde onderzoek een hogere verteerbaarheid en daarmee een hogere energiewaarde dan ingekuild gras. Bovendien neemt de eiwitbestendigheid door kunstmatig drogen toe, waardoor de DVE-waarde hoger en de OEB-waarde lager was dan bij grasklaverkuil. In tabel 3.3 staan de resultaten van de voeropname en melkproductie van de drie proefgroepen weergegeven (Klop et al., 2004).

Tabel 3.3 Voeropname ( $k g d s$ ) en melkproductie per koe per dag (Klop et al., 2004).

\begin{tabular}{|c|c|c|c|}
\hline & Najaarskuil & Grasbrok & Mengvoer \\
\hline \multicolumn{4}{|l|}{ Voeropname } \\
\hline Basisrantsoen & 9,7 & 13,3 & 13,5 \\
\hline + najaarskuil & 5,0 & - & - \\
\hline + grasbrok & - & 2,6 & - \\
\hline+ mengvoer & - & - & 2,0 \\
\hline Aanvullend krachtvoer & $\underline{4,0}$ & $\underline{4,0}$ & $\underline{4,0}$ \\
\hline Totaal & 17,7 & 19,9 & 19,5 \\
\hline \multicolumn{4}{|l|}{ Melkproductie } \\
\hline Melkgift (kg) & 21,6 & 23,7 & 23,3 \\
\hline Vet $(\%)$ & 4,65 & 4,43 & 4,65 \\
\hline Eiwit (\%) & 3,31 & 3,35 & 3,44 \\
\hline Ureum & 24,2 & 20,8 & 20,4 \\
\hline
\end{tabular}

\subsubsection{Grasbrok versus ingekuild gras}

In 2002 is op Aver Heino een deel van de najaarssnede grasklaver (maaidatum 2 september) na voordrogen ingekuild, terwijl de rest werd gedroogd tot grasbrok. In tabel 3.4 staat de voederwaarde van de najaarskuil en grasbrok weergegeven (Klop et al., 2004). 
Tabel 3.4 Voederwaarde najaarskuil en grasbrok (Klop et al., 2004).

\begin{tabular}{lcc}
$\quad$ Parameter & Najaarskuil & Grasbrok \\
Droge stof $(\mathrm{g} / \mathrm{kg})$ & 423 & 948 \\
\hline Ruw eiwit (incl. $\left.\mathrm{NH}_{3}\right)(\mathrm{g} / \mathrm{kg} \mathrm{ds})$ & 210 & 216 \\
\hline Verteringscoëfficient $(\%)$ & 68,9 & 76,6 \\
\hline VEM & 765 & 869 \\
\hline DVE $(\mathrm{g} / \mathrm{kg}$ ds) & 61 & 94 \\
\hline OEB $(\mathrm{g} / \mathrm{kg} \mathrm{ds})$ & 72 & 33 \\
\hline
\end{tabular}

De voeropname van de koeien in de proefgroep met najaarskuil was lager dan van de koeien in de proefgroepen met grasbrok en aanvullend eiwitrijk mengvoer. De lagere voeropname was een gevolg van een andere ruwvoer/krachtvoerverhouding. Het rantsoen met de najaarskuil bestond uit meer ruwvoer en verhoudingsgewijs minder krachtvoer. Ruwvoer heeft een hogere verzadigingswaarde en daarmee is de voeropnamecapaciteit van de koeien lager. De lagere voeropname resulteerde in een lagere melkproductie. De proefgroep met het aanvullend eiwitrijke mengvoer had het hoogste eiwitgehalte. De proefgroep met de grasbrok had het laagste melkvetgehalte (Klop et al., 2004). In het Bioveem project zijn op drie biologische melkveebedrijven in het najaar van 2003 grasklaverbrok en grasklaverkuil vergeleken. De ervaringen van de biologische melkveehouders waren dat ze grasbrok ervaarden als een smakelijk voedermiddel voor melkvee. Het voordeel dat grasklaverbrok in het rantsoen oplevert, hangt sterk af van de weersomstandigheden tijdens de voederwinning. De veehouders benadrukten dat grasbrok voldoende eiwit moet bevatten, wat men kan bereiken door in een jong stadium te maaien.

\subsubsection{Verteerbaarheid: een belangrijke factor}

Naast de kwaliteit van het voedsel is verteerbaarheid een belangrijke voerkarakteristiek die de productie van enterische methane kan beïnvloeden. Factoren zoals rijpheid bij de oogst en conserveringsmethode (hooi, kuilvoer, droogproces, pelleteren) kunnen allemaal van invloed zijn op de kwaliteit en verteerbaarheid van het voer. Het verhogen van de kwaliteit of verteerbaarheid van voedergewassen zal de productie-efficiëntie verhogen en dit kan resulteren in een verminderde $\mathrm{CH}_{4}$ uitstoot (Yáñez-Ruiz et al., 2017).

Vers jong gras van $10 \mathrm{~cm}$ tot $15 \mathrm{~cm}$ lang is ideaal voer, het eiwitgehalte waarvan de voedingswaarde afhangt, is hoger dan dat van bijna elk ander voer. Zijn zetmeelwaarde wordt alleen overtroffen door maïs; het is rijk aan minerale zouten, die geleidelijk op een natuurlijke manier worden opgenomen, wat onmogelijk is met de vervangers die in de winter worden gebruikt, wanneer de groei van jonge dieren vertraagt. Goed gedroogd gras behoudt al deze waardevolle eigenschappen in een goed verteerbare vorm en hierin ligt de reden waarom het drogen van gras in het middelpunt van de belangstelling staat.

\subsection{Eiwit van eigen land}

Eiwit van eigen land is een maatregel om stikstofinputs in de Nederlandse melkveehouderij te verlagen. Een concrete ambitie die is uitgesproken door de DMS-commissie ${ }^{3}$, LTO Vakgroep Melkveehouderij en de NZO (Nederlandse Zuivel Organisatie) is uitgesproken luidt als volgt: voor 2025, 65\% eiwit van eigen bodem moet komen, of binnen een straal van $20 \mathrm{~km}$ moet worden aangekocht via buurtcontracten ${ }^{4}$. Grasdrogen kan hier potentieel aan bijdragen omdat het de kwaliteit van eigen ruwvoeder, en dus ook het eiwitgehalte, kan verhogen. Zie hiervoor de voorgaande hoofdstukken.

\section{Definitie eiwit van eigen land}

De eerste stap om de bestaande situatie van eiwitvoorziening uit eigen grond te bepalen, is het definiëren van een indicator. Deze indicator geeft aan hoeveel eiwit er is gerealiseerd op eigen land, rekening houdend met conserveringsverliezen. Hierna wordt gecontroleerd hoeveel eiwit de kudde

\footnotetext{
${ }^{3}$ Dirksen Management Support B.V.

${ }^{4}$ https://www.melkvee100plus.nl/Artikelen/Management/2019/2/Sleutelen-aan-meer-eiwit-van-eigen-land-386791E/
} 
verbruikt, waarbij voerverliezen worden berekend (restvoer). Door het geteelde eiwit te delen door het gevoerde eiwit, wordt het percentage eiwit van eigen land berekend.

$$
\text { Eiwit van eigen land }=\frac{\text { Eigen geteeld eiwit in veevoer (uitgedrukt in } \mathrm{kg} \mathrm{N})}{\text { Eiwit verbruik door veestapel (uitgedrukt in } \mathrm{kg} \mathrm{N})} \times 100 \%
$$

Voor deze index is voorgesteld om het te berekenen over een periode van drie jaar. Zo wordt verzekerd dat extreme veranderingen in kudde-eigenschappen zoals voorraadmutatie gemiddeld worden (Philipsen et al., 2020). Het eigen geteelde eiwit wordt in de berekening gecorrigeerd voor conserveringsverliezen, waarbij de conserveringsverliezen niet worden meegeteld als eigen geteeld eiwit. De teelt van akkerbouwproducten wordt alleen meegenomen als deze ook daadwerkelijk als veevoer aan de koeien wordt gevoerd. Het eiwitverbruik door de veestapel wordt gecorrigeerd voor vervoederingsverliezen, waarbij de vervoederingsverliezen meetellen bij het berekening.

Door deze index op boerderijniveau te schatten, zijn boeren in staat om hun eigen zelfvoorziening op eiwit in te schatten. Hoewel er op managementniveau veel kan worden gestuurd om de index te verhogen, kan het ook simpelweg worden behaald door een hogere eiwitopbrengst per hectare te behalen en dit aan de koeien te voeren.

\section{De potentiële rol van grasdrogen}

Het percentage 'eiwit van eigen land' kan verhoogd worden door het gras kunstmatig te drogen in plaats van in te kuilen. Door de verminderde verliezen wordt namelijk een betere benutting van het eigen geteelde voer gerealiseerd. Door een betere benutting van eigen geteeld voer hoeft er ook minder voer aangekocht te worden, waardoor de verhouding tussen eigen voer en aangekocht voer wordt verbeterd. Als laatste maakt de verbeterde kwaliteit van het eigen voer ook een betere voerconversie, waardoor minder eiwit van buitenaf nodig is om de veestapel te voeren.

Kortom de invloed van gras drogen op het percentage 'eiwit van eigen land' draait vooral om het eigen geteelde eiwit zo goed mogelijk te laten benutten door het vee: dus de eiwitbehoefte (DVE i.c. m. OEB) van het vee zoveel mogelijk invullen met (ruw) voeders van eigen land, maar ook verlagen van de veld- en voederverliezen dragen er aan bij. Gedroogd gras biedt daarnaast potentie om lagere OEB te voeren (in vergelijking met kuil). Hierdoor is de eiwitvertering en daarmee ook een betere benutting en melkproductie. Maar, dit hangt ook af van de bedrijfsspecifieke omstandigheden. Het totale rantsoen moet kloppen, niet alleen DVE en OEB (incl. voerkosten). Een hogere OEB kan men ook compenseren door voedergrondstoffen met veel energie (en een negatieve OEB) er tegenover te zetten.

\subsection{Minder afhankelijkheid van krachtvoer}

Krachtvoer beperken is een manier om de eiwit inputs te verlagen op het melkveebedrijf. Om krachtvoer te kunnen vervangen, moeten de grasbrokken ook van krachtvoerkwaliteit zijn. De kwaliteit van het gemaaide gras bepaalt wat de voedingswaarde in de grasbrok zal zijn, en dus zal de snede van goede kwaliteit moeten zijn om krachtvoer 1-op-1 te kunnen vervangen. Een optie kan zijn om de grasbrokken van verschillende snedes te mengen om jaarrond een goede kwaliteit (of gemiddelde kwaliteit) gedroogd grasvoer te kunnen voeren. Een andere mogelijkheid is om de kwaliteit van de grasbrokken te differentiëren naar de behoeften van diergroepen (melkvee, droge koeien, jongvee). Dit zou helpen om de voerconversie-efficiëntie van het gras te verbeteren.

In de KringloopWijzer 2018, een managementtool die de mineralenefficiëntie van een bedrijf in kaart brengt, zijn enkele beperkingen te signaleren ten aanzien van kenmerken van grasvoer. De verschillen tussen kuilgras en gedroogd gras worden daarbij als volgt aangepakt:

- Er wordt in de huidige KringloopWijzer geen onderscheid gemaakt in conserveringsverliezen tussen kuilgras en gras dat kunstmatig gedroogd is. Voor beide wordt dezelfde waarden gehanteerd.

- In de KringloopWijzer wordt niet met DVE en OEB gerekend, maar alleen met (verteerbaar) ruw eiwit. 
- $\quad$ Er worden in de KringloopWijzer wel verschillende berekeningswijzen gehanteerd om de verteringscoëfficiënt van het ruw eiwit te schatten van kuilgras en gedroogd gras. De verteringscoëfficiënt van het ruw eiwit kan gebruikt worden om te bepalen welk deel van het niet-benutte stikstof terecht komt in de urine. Bij een gelijke benutting van de stikstof betekent een hogere verteringscoëfficiënt dat meer stikstof in de urine terechtkomt. En hoe meer stikstof in de urine, hoe hoger de potentiële ammoniakemissie. Anderzijds betekent een hogere verteringscoëfficiënt dat het eiwit beter benut wordt door het vee en dus met minder voer toe kan. Belangrijk is dus het aanbod goed af te stemmen op de behoefte van het vee, zodat er een goede benutting van stikstof (eiwit) plaatsvindt.

- Op dit moment is de kringloopwijzer dus te weinig specifiek om de voordelen van gedroogd gras boven kuilgras te berekenen (zie ook paragrafen 3.1 en 3.2) 


\section{$4 \quad \mathrm{CO}_{2}$-footprint en energieverbruik van grasdrogen}

\subsection{Scenarioberekeningen voor fossiele brandstof en groene stroom}

In deze paragraaf is de $\mathrm{CO}_{2}$-footprint en het energieverbruik van grasdroging ingeschat voor twee mogelijke opties, namelijk als centrale grasdroger (regionale schaal) en een decentrale grasdroger (boerderijschaal). Elk scenario is onderzocht met verschillende situaties qua energievoorziening: combinatie van kolen en grijze stroom, grijze stroom, combinatie van kolen en groene stroom en groene stroom. Aangenomen is dat de grasdroger op de boerderij alleen op elektriciteit werkt en dat er geen kolen (of houtpellets) worden gebruikt.

Elke energiebron heeft een zogenaamde emissiefactor die aangeeft hoeveel gram $\mathrm{CO}_{2}$-eq. per $\mathrm{MJ}$ wordt uitgestoten. Voor het schatten van de $\mathrm{CO}_{2}$-footprint zijn standaard emissiefactoren afgeleid van Ecoinvent (Wernet et al., 2016). Voor grijze elektriciteit is de emissiefactor 201,9 gram $\mathrm{CO}_{2}$-eq per MJ, en voor groene elektriciteit 4,34 gram $\mathrm{CO}_{2}$-eq per $\mathrm{MJ}$ (er worden $\mathrm{CO}_{2}$ emissies toegekend die ontstaan bij fabricage, installatie en onderhoud). Groene elektriciteit heeft daarmee bijna een $98 \%$ lagere emissiefactor.

Specifieke praktijksituaties zijn niet getoetst. Uitgangspunt is dat zes sneden geoogst worden, die allemaal gedroogd worden. De uitgerekende varianten zijn voor het produceren van grasbrok, omdat dit interessanter is m.b.t. het vervangen van krachtvoer. Het effect van minder veldwerk (schudden, wiersen, aanrijden) is niet meegenomen in deze berekeningen. Voor de productie van gras (hierin zit bijvoorbeeld bemesten, kunstmest, maaien, schudden, wiersen) wordt voor alle scenario's dezelfde standaard $\mathrm{CO}_{2}$-footprint aangehouden. Bij de uitgevoerde berekeningen draagt de $\mathrm{CO}_{2}$-footprint van deze productie substantieel bij aan de totale footprint ( $519 \mathrm{~g}$ per $\mathrm{kg} \mathrm{ds}$ ).

\section{Veronderstellingen grasdroging op centrale grasdrogerijschaal}

Bij het grasdrogen in een centrale grasdrogerij wordt gebruikt gemaakt van verschillende energiebronnen:

- Diesel voor transport van en naar grasdrogerij,

- Kolen voor het droogproces,

- Elektriciteit voor procesbesturing,

- $\quad$ Elektriciteit en gas voor malen en pelleteren van grasbrok.

Om grasbrok volledig met duurzame energie te kunnen maken zullen de fossiele energiebronnen vervangen moeten worden door elektriciteit. Hier is nog geen ervaring mee. Zodoende zijn op basis van energievraag aannames gedaan.

Voor de centrale grasdrogerij zijn de varianten (resultaten berekening in tabel 4.1):

- Centrale Drogerij warmteproductie met kolen en gas (huidige praktijk, energiebronnen zoals hierboven opgenoemd) overig energieverbruik grijze elektriciteit.

- Centrale Drogerij warmteproductie met kolen en gas (huidige praktijk, energiebronnen zoals hierboven opgenoemd) overig energieverbruik groene elektriciteit.

- Centrale drogerij warmteproductie met grijze elektriciteit:

- Diesel voor transport van en naar grasdrogerij,

- Elektriciteit voor het droogproces,

- Elektriciteit voor procesbesturing,

- Elektriciteit voor malen en pelleteren van grasbrok.

- Centrale drogerij warmteproductie met groene elektriciteit.

- Zelfde punten als hierboven, maar dan uitgaande van groene elektriciteit. 
Per snede is uitgegaan van een opbrengst van $3.000 \mathrm{~kg}$ ds per hectare. Een wisselende opbrengst bij de oogst wordt in de praktijk verwacht. De $\mathrm{CO}_{2}$-footprint van gras vóór de oogst werd verondersteld $519 \mathrm{~g} \mathrm{CO}_{2}$-eq/kg ds te zijn. Dit is een aanname die in dit onderzoek is gebruikt, maar kan worden verminderd door te werken met fossielvrije mechanisatie (waterstoftractor, elektrische tractor of CNGtractor op groen gas).

Voor het produceren van hoogwaardige warmte uit elektriciteit is uitgegaan van een rendement van $70 \%$. Dit is puur een aanname, geredeneerd is als volgt: hoogwaardige warmte maken uit elektriciteit benaderd een efficiency van $100 \%$, als deze warmte tijdelijk moet worden opgeslagen gaan we uit van een verlies in rendement van $30 \%$. Voor het transport van het grasland tot de centrale schaal grasdroger, wordt er uitgegaan van een inkomende/uitgaande afstand van $50 \mathrm{~km}$. Een lijst met aannames en rekenregels is opgenomen in bijlage 1 en 2 .

Tabel 4.1 De $\mathrm{CO}_{2}$-footprint van grasbrok centrale drogerij bij verschillende drogestofgehalten in het aangeleverde gras en eindproduct (incl. transport; excl. effecten op pensfermentatie en mestopslag) (in $\mathrm{g} \mathrm{CO}_{2}$-eq per $\mathrm{kg} d s$ ). Per snede is uitgegaan van een opbrengst van $3.000 \mathrm{~kg}$ ds per hectare.

\begin{tabular}{|c|c|c|c|c|c|c|}
\hline Snede & 1 & 2 & 3 & 4 & 5 & 6 \\
\hline ds bij oogst (\%) & 20 & 30 & 40 & 50 & 20 & 50 \\
\hline \multicolumn{7}{|c|}{ Centrale drogerij regulier kolengestookt en grijze stroom* } \\
\hline \multicolumn{7}{|c|}{ Centrale drogerij regulier kolengestookt en groene stroom* } \\
\hline & 2.418 & 1.749 & 1.351 & 1.113 & 2.514 & 1.083 \\
\hline \multicolumn{7}{|c|}{ Drogerij elektrificatie met grijze stroom* } \\
\hline & 4.850 & 3.098 & 2.223 & 1.697 & 4.774 & 1.621 \\
\hline
\end{tabular}

*Voor het verkrijgen van het gras vanaf het grasland (met een conventioneel systeem) is voor alle varianten gerekend met $519 \mathrm{gCO} 2 \mathrm{eq} / \mathrm{kg} \mathrm{ds}$.

\section{Veronderstellingen grasdroging op boerderijschaal}

Voor het drogen van gras op de boerderij worden varianten ingedeeld op basis van het rendement van de productie van warmte- en energiebron. Elke variant is ingedeeld in verschillende sub-varianten:

a. Rendement van $500 \%$ voor het produceren van laagwaardige warmte, inclusief de volgende vier sub-varianten (resultaten berekening in tabel 4.2):

- Decentrale grasdroging met grijze elektriciteit en voordrogen

- Elektriciteit voor het droogproces,

- Elektriciteit voor procesbesturing,

- Elektriciteit voor malen en pelleteren van grasbrok.

- Decentrale grasdroging groene elektriciteit met voordrogen

- Zelfde punten als hierboven maar dan met groene elektriciteit

- Decentrale grasdroging met grijze elektriciteit en zonder voordrogen

- Elektriciteit voor het droogproces,

- Elektriciteit voor procesbesturing,

- Elektriciteit voor malen en pelleteren van grasbrok.

- Decentrale grasdroging met groene elektriciteit en zonder voordrogen

- Zelfde punten als hierboven maar dan met groene elektriciteit

b. Rendement van $70 \%$ voor het produceren van hoogwaardige warmte uit elektriciteit inclusief de volgende vier sub-varianten (resultaten berekening in tabel 4.3):

- Zelfde punten als variant "a" maar dan met $70 \%$ rendement.

Per snede is uitgegaan van een opbrengst van $3.000 \mathrm{~kg}$ ds per hectare. In de praktijk wordt een wisselende opbrengst bij de oogst verwacht. De $\mathrm{CO}_{2}$-footprint van gras vóór de oogst werd 
verondersteld $519 \mathrm{~g} \mathrm{CO}_{2}-\mathrm{eq} / \mathrm{kg}$ ds te zijn. Dit is een aanname die in dit onderzoek is gebruikt, maar kan worden verminderd door te werken met fossielvrije mechanisatie (waterstoftractor, elektrische tractor of CNG-tractor op groen gas). Voor het transport van het grasland tot de boerderijschaal grasdroger wordt er uitgegaan van een inkomende en uitgaande afstand van 5 en $1 \mathrm{~km}$, respectievelijk.

Voor het produceren van laagwaardige warmte (restwarmte) is uitgegaan van een rendement van $500 \%$. Door middel van een warmtepomp wordt voorzien in de verwarming van de ingaande lucht. Droging op boerderijschaal vindt plaats onder lagere temperaturen dan een centrale grasdrogerij. Hierbij wordt uitgegaan van een hooibox systeem waarbij sprake is van langzame droging (zie ook Nieuwe Oogst 9 maart 2019). Op basis van deze aannames kan het energieverbruik waarschijnlijk overschat zijn. Als de verdampingswarmte door warme droge lucht geleverd kan worden, zal het energieverbuik aanzienlijk lager zijn. Het is ook mogelijk om de warmte van de zon onder het dak of de warme lucht door geforceerde ventilatie te gebruiken in het droogproces, waardoor er veel minder energie nodig is.

Tabel 4.2 De $\mathrm{CO}_{2}$-footprint van grasbrok drogerij boerenbedrijf met laagwaardige warmte en voordrogen als variant en bij verschillende drogestofgehalten in eindproduct (incl. transport; excl. effecten op pensfermentatie en mestopslag) (in $\mathrm{g} \mathrm{CO}_{2}$-eq per $\mathrm{kg} \mathrm{ds}$ ). Per snede is uitgegaan van een opbrengst van $3.000 \mathrm{~kg}$ ds per hectare.

\begin{tabular}{|c|c|c|c|c|c|c|}
\hline Snede & 1 & 2 & 3 & 4 & 5 & 6 \\
\hline \multicolumn{7}{|c|}{ Variant 1: met voordrogen } \\
\hline ds na voordrogen (\%) & 60 & 60 & 60 & 60 & 60 & 60 \\
\hline ds na drogen (\%) & 92 & 92 & 92 & 92 & 85 & 85 \\
\hline \multicolumn{7}{|c|}{ Boerderijschaal Grijze stroom*\# } \\
\hline \multicolumn{7}{|c|}{ Boerderijschaal Groene stroom*\# } \\
\hline & 528 & 528 & 528 & 528 & 528 & 528 \\
\hline \multicolumn{7}{|c|}{ Variant 2: zonder voordrogen } \\
\hline ds bij oogst (\%) & 20 & 30 & 40 & 50 & 20 & 50 \\
\hline & 1385 & 1080 & 928 & 837 & 1381 & 833 \\
\hline \multicolumn{7}{|c|}{ Boerderijschaal Groene stroom*\# } \\
\hline & 568 & 553 & 546 & 541 & 568 & 541 \\
\hline
\end{tabular}

* In de praktijk worden dergelijke drogerijen verwarmt met restwarmte (onder dak) en pellet kachels.

\#Voor het verkrijgen van het gras vanaf het land is voor alle varianten gerekend met $519 \mathrm{~g} \mathrm{CO} 2 \mathrm{eq} / \mathrm{kg} \mathrm{ds}$.

Voor de productie van hoogwaardige warmte uit elektriciteit, dezelfde aanname als centrale grasdroging werd gemaakt voor hoogwaardige warmte. Het doel van deze aanname om de $\mathrm{CO}_{2}-$ footprint in te schatten, wanneer het drogen op boerderijschaal plaatsvindt bij hoge temperaturen. 
Tabel 4.3 De $\mathrm{CO}_{2}$-footprint van een grasbrokdrogerij boerenbedrijf met hoogwaardige warmte en voordrogen als variant en bij verschillende drogestofgehalten in eindproduct (incl. transport; excl. effecten op pensfermentatie en mestopslag) (in $\mathrm{g} \mathrm{CO}_{2}$-eq per $\mathrm{kg} \mathrm{ds}$ ). Per snede is uitgegaan van een opbrengst van $3.000 \mathrm{~kg}$ ds per hectare.

\begin{tabular}{|c|c|c|c|c|c|c|}
\hline Snede & 1 & 2 & 3 & 4 & 5 & 6 \\
\hline ds na voordrogen (\%) & 60 & 60 & 60 & 60 & 60 & 60 \\
\hline ds na drogen (\%) & 92 & 92 & 92 & 92 & 85 & 85 \\
\hline \multicolumn{7}{|c|}{ Boerderijschaal Grijze stroom*\# } \\
\hline \multicolumn{7}{|c|}{ Boerderijschaal Groene stroom*\# } \\
\hline & 538.4 & 538.4 & 538.4 & 538.4 & 536.8 & 536.8 \\
\hline \multicolumn{7}{|c|}{ Variant 2: zonder voordrogen } \\
\hline ds bij oogst (\%) & 20 & 30 & 40 & 50 & 20 & 50 \\
\hline \multicolumn{7}{|c|}{ Boerderijschaal Grijze stroom ${ }^{* \#}$} \\
\hline & 4850 & 3098 & 2223 & 1697 & 4774 & 1621 \\
\hline \multicolumn{7}{|c|}{ Boerderijschaal Groene stroom*\# } \\
\hline & 642 & 596 & 573 & 560 & 641 & 558 \\
\hline
\end{tabular}

* In de praktijk worden dergelijke drogerijen verwarmt met restwarmte (onder dak) en pellet kachels.

\#Voor het verkrijgen van het gras vanaf het land is voor alle varianten gerekend met $519 \mathrm{~g} \mathrm{CO} 2 \mathrm{eq} / \mathrm{kg} \mathrm{ds}$.

\section{Vergelijkingen verschillende varianten}

\section{Varianten van centrale grasdrogerii}

Een vergelijking van de gemiddelde prestaties van verschillende varianten op centrale grasdrogerij wordt gegeven in figuur 4.1. Hieruit bleek dat de overgang van kolengestookte naar grijze stroom, gemiddeld leidt tot een toename van de gemiddelde $\mathrm{CO}_{2}$-footprint per kg droge stof (een stijging van bijna 70\%). Deze toename geldt ook als de combinatie van kolengestookte brandstof en groene stroom wordt vervangen door grijze stroom. Bij de gekozen uitgangspunten is een kolengestookte grasdroogcentrale vanuit $\mathrm{CO}_{2}$-footprint effectiever. Dit is te verklaren doordat de belangrijkste bron voor grijze elektriciteit fossiele brandstoffen zijn, zoals aardgas en steenkool, daarnaast is verhitten/droging met grijze stroom als minder efficiënt ingeschaald dan direct verwarmen met kolen. Als groene stroom echter de enige energiebron is, zal de gemiddelde $\mathrm{CO}_{2}$-footprint per kg droge stof sterk afnemen (een reductie van bijna $70 \%$ ten opzichte van kolen). Deze reductie is nog groter wanneer grijze stroom wordt vervangen door groene stroom (ongeveer $80 \%$ ). Een combinatie van kolengestookte brandstof en groene stroom draagt niet sterk bij aan de reductie van $\mathrm{CO}_{2}$ vergeleken met een variant waar kolengestookte brandstof wordt gecombineerd met grijze stroom (ongeveer $5 \%)$. 

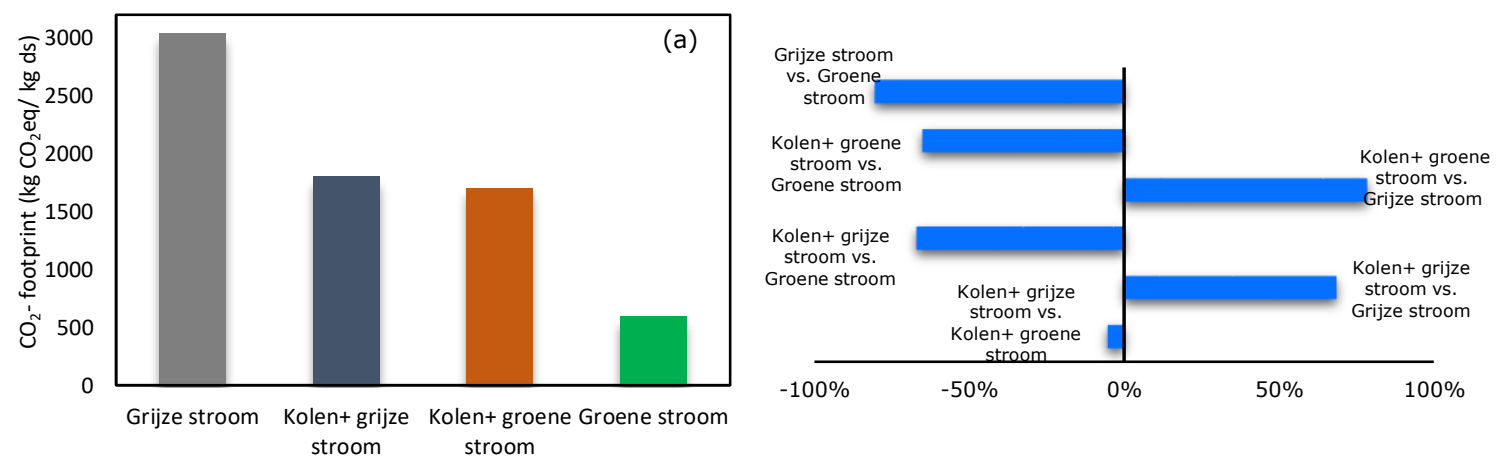

Figuur 4.1 a) De gemiddelde $\mathrm{CO}_{2}$-footprint en b) het verschil tussen verschillende varianten van de centrale grasdroger in termen van vermindering van de $\mathrm{CO}_{2}$-footprint. Waarden zijn in procenten (\%) (de eerst genoemde variant is de referentie). Waarden aan de linkerkant van (b) geven een verminderde $\mathrm{CO}_{2}$-footprint aan en waarden aan de rechterkant geven een verhoogde $\mathrm{CO}_{2}$-footprint aan.

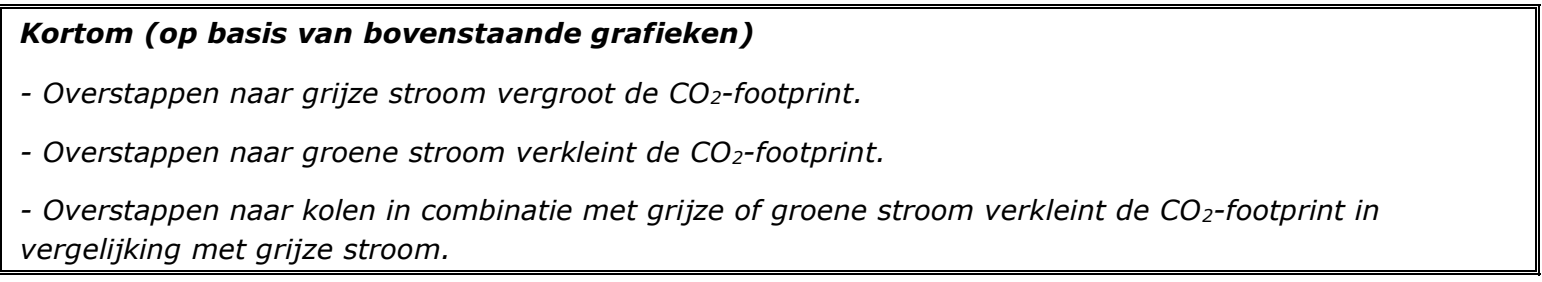

\section{Varianten van boerderijschaal grasdrogerij}

Een vergelijking van de gemiddelde prestaties van grasdrogerij voor de verschillende varianten op boerderijschaal wordt gegeven in figuur 4.2 en figuur 4.3 . In figuur 4.2 , is de variant met laagwaardige warmte en in figuur 4.3 de variant met hoogwaardige warmte weergegeven. Index 1 en 2 geven varianten aan met respectievelijk voordroging en zonder voordroging.

Bij vergelijking van de resultaten van de eerste variant (met voordrogen en laagwaardige warmte) bleek dat het vermijden van voordrogen gemiddeld leidt tot een verhoging van de gemiddelde $\mathrm{CO}_{2}$ footprint per $\mathrm{kg}$ droge stof (een stijging van bijna $33 \%$ bij grijze elektriciteit en $5 \%$ bij groene stroom).

Voor verwerking op boerderijschaal is de impact van elektriciteitsverbruik kleiner voor de $\mathrm{CO}_{2}-$ footprint, aangezien we uitgaan van grasaanvoer met een hoger drogestofgehalte, echter wanneer het drogestofgehalte van het gras afneemt en grasdrogen plaatsvindt met laagwaardige warmte, zal de impact toenemen, maar nog steeds in mindere mate dan het grijze elektriciteitsscenario.

\footnotetext{
Kortom:

- Overstappen naar voordroging verkleint de $\mathrm{CO}_{2}$-footprint (scenario's met index 1).

- Overstappen naar groene stroom verkleint de $\mathrm{CO}_{2}$-footprint.
} 

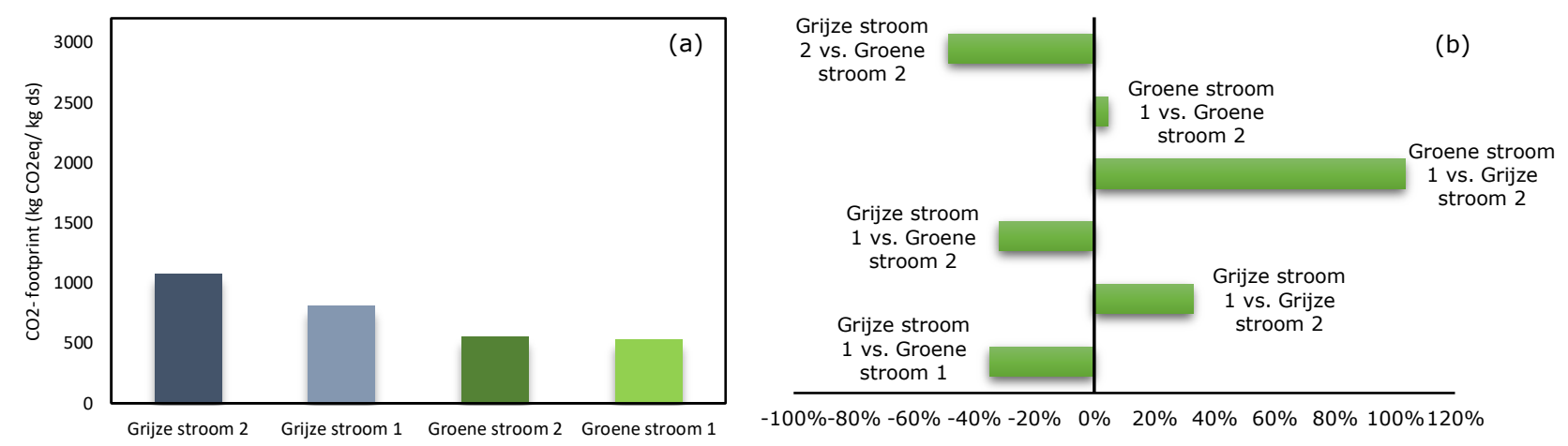

Figuur 4.2 a) De gemiddelde $\mathrm{CO}_{2}$-footprint (index 1 geeft een variant aan met voordroging bij oogst, index 2 geeft een variant aan met zonder voordroging bij oogst). b) het verschil tussen verschillende energiebronnen van de boerderijschaal grasdroger met laagwaardige warmte in termen van vermindering van de $\mathrm{CO}_{2}$-footprint. Waarden zijn in procenten (\%) (de eerst genoemde variant is de referentie). Waarden aan de linkerkant van (b) geven een verminderde $\mathrm{CO}_{2}$-footprint aan en waarden aan de rechterkant geven een verhoogde $\mathrm{CO}_{2}$-footprint aan.

Bij vergelijking van de resultaten van de tweede variant (zonder voordroging en hoogwaardige warmte?) bleek dat het vermijden van voordrogen gemiddeld leidt tot een verhoging van de gemiddelde CO2-footprint per kg droge stof (een stijging van bijna $136 \%$ bij grijze elektriciteit en $10 \%$ bij groene stroom ten opzichte van vergelijkbare varianten met voordrogen).

Bij gebruik van hoogwaardige warmte wordt de $\mathrm{CO}_{2}$-footprint vergroot ten opzichte van laagwaardige warmte en nog hoger als er niet wordt voorgedroogd (Dit wordt duidelijk door het vergelijken van fig 4.2 en 4.3$)$.

\section{Kortom (op basis van bovenstaande grafieken)}

- Overstappen naar voordroging verkleint de $\mathrm{CO}_{2}$-footprint (scenario's met index 1 ).

- Overstappen naar hoogwaardige warmte verhoogt de $\mathrm{CO}_{2}$-footprint (vergeleken met figuur 4.2-a).

- Overstappen naar groene stroom verkleint de $\mathrm{CO}_{2}$-footprint. 

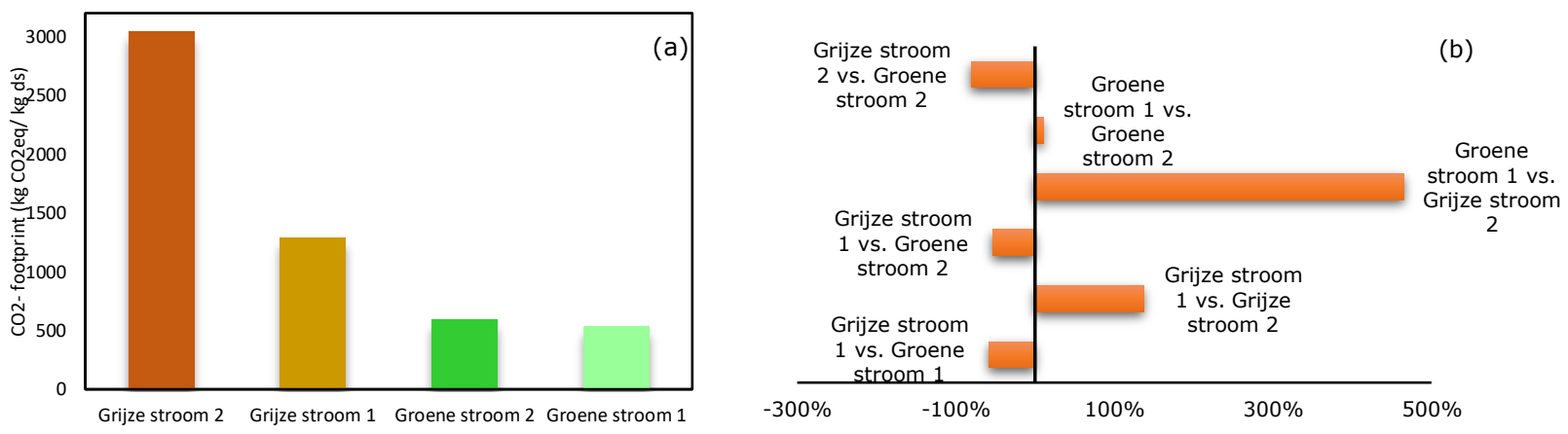

Figuur 4.3 a) De gemiddelde $\mathrm{CO}_{2}$-footprint

(index 1 geeft een variant aan met voordroging bij oogst, index 2 geeft een variant aan met zonder voordroging bij oogst). b) Het verschil tussen verschillende energiebronnen van de boerderijschaal grasdroger met hoogwaardige warmte in termen van vermindering van de $\mathrm{CO}_{2}$-footprint. Waarden zijn in procenten (\%) (de eerst genoemde variant is de referentie). Waarden aan de linkerkant van (b) geven een verminderde $\mathrm{CO}_{2}-$ footprint aan en waarden aan de rechterkant geven een verhoogde $\mathrm{CO}_{2}$-footprint aan.

\subsection{Stroomverbruik}

\section{Regionaal drogen van gras}

Op regionale schaal zou het mogelijk kunnen zijn om tijdens piekuren zoveel mogelijk stroom af te nemen voor een grasdroger. Dan is het denkbaar om gras bij hogere temperaturen te drogen, dan met reguliere warmtewisselaars kan worden bereikt. Er zal dan sprake zijn van overcapaciteit van de installatie met hogere elektriciteitsverbruik tot gevolg, maar deze elektriciteitsconsumptie kan de productie tijdens piekuren in de zomer in balans brengen. Deze installaties kunnen worden aangesloten op het middenspanningsnet ( $>400$ Volt net $<50 \mathrm{kV}$ ) of het hoogspanningsnet ( $>110 \mathrm{kV}$ ). Dit is mogelijk wanneer een groep boeren investeert in grasdrogers. In dit geval kan een warmtebuffer te gebruiken waarin de overtollige/overschot elektriciteit wordt omgezet in warmte, die later weer kan worden gebruikt voor het drogen van gras.

\section{Boerderijschaal}

Voor de grasdrogerij op boerderijschaal en met lage temperatuur is op basis van uitgangspunten (o.a. droging van al het geoogste gras $18.000 \mathrm{~kg}$ droge stof/hectare) berekend, dat circa $16.000 \mathrm{kWh}$ per hectare per jaar verbruikt kan worden voor het droogproces. Uitgaande van een opbrengst van 270 kWh per zonnepaneel en ervan uitgaande dat alle opbrengsten per jaar worden geëxtraheerd om te gebruiken voor het drogen van gras, zouden grofweg 60 panelen per hectare grasland gecompenseerd kunnen worden. Bij de band- of trommeldroger op boerderijschaal waarbij met hoge temperatuur gedroogd wordt, zal een hoger energie verbruik nodig zijn voor het droogproces.

Door de energietransitie en het gebruik van steeds meer lokale opwekking van elektriciteit, is er grote behoefte aan stabilisatie van vraag en aanbod op het laagste netniveau (boerderijschaal). Dit voorkomt investeringen in het upgraden van lokale netwerken om deze fluctuaties op te vangen. Grasdroging op boerderijen met hoge temperaturen kan een cruciale rol spelen als buffer om overproductie tijdens piekuren in de zomer in evenwicht te brengen. In dit opzicht wordt verwacht dat grasdrogers op bedrijfsniveau die op zonne-energie werken, vooral in de zomer het aanbod en de vraag van elektriciteit in een elektriciteitsnet met overproductie gedeeltelijk in evenwicht brengen. Het type droger en de kenmerken ervan zijn bedrijfsspecifiek, dus dit rapport heeft er geen rekening mee gehouden. Deze drogers voor veehouderijen kunnen ingezet worden om het laagspanningsnet $(<400$ Volt) en/of het middenspanningsnet ( $>400$ Volt netwerk $<50 \mathrm{kV}$ ) te balanceren. 


\subsection{Effect minder krachtvoerverbruik}

De $\mathrm{CO}_{2}$-footprint van krachtvoer hangt af van de samenstelling en gebruikte grondstoffen in het krachtvoer. De KringloopWijzer 2018 heeft een eenvoudige methode gehanteerd door één waarde te hanteren voor de $\mathrm{CO}_{2}$-footprint van het mengvoer, dat gebaseerd is op de gemiddelde samenstelling van het mengvoer in Nederland. Voor 2018 is daarvoor de waarde van $1.222 \mathrm{~g} \mathrm{CO}_{2}$-eq per kg product (= $1.364 \mathrm{~g} \mathrm{CO}_{2}$-eq per kg ds) gehanteerd. In de KringloopWijzer 2020 wordt van elk mengvoer naast de standaardgehalten (VEM, $\mathrm{RE}, \mathrm{P}$, etc.) ook de $\mathrm{CO}_{2}$-footprint van dat specifieke mengvoer opgegeven, die gebaseerd is op de gebruikte grondstoffen op dat mengvoer. In dit onderzoek berekenen we de gemiddelde $\mathrm{CO}_{2}$-footprint van verschillende grasdroogtechnieken. Op basis van de resultaten had een kolengestookte centrale grasdroger een 34\% hogere $\mathrm{CO}_{2}$-footprint dan krachtvoer, terwijl de elektrificatie van de centrale grasdrooginstallatie met groene stroom, grasdrogende grijze stroom op boerderijschaal, grasdrogende groene stroom op boerderijschaal respectievelijk een $-56 \%$, $-40 \%$ en $-61 \%$ lagere $\mathrm{CO}_{2}$-footprint had (Tabel 4.4 ).

Tabel 4.4 Het verschil tussen krachtvoer en gedroogd gras bij verschillende methoden. Waarden met groene pijl duiden op een hogere $\mathrm{CO}_{2}$-footprint en waarden met rode pijl duiden op een lagere $\mathrm{CO}_{2}$-footprint.

\begin{tabular}{|c|c|c|}
\hline $\mathrm{CO}_{2}$-eq footprint & $\mathrm{g} \mathrm{CO}_{2}$-eq per $\mathrm{kg} \mathrm{ds}$ & $\%$ verschil (B-A/A) \\
\hline A. Krachtvoer & 1346 & \\
\hline Grasbrok & & \\
\hline Centrale grasdrogerij - kolengestookt & 1804 & $34 \%$ பे \\
\hline Centrale grasdrogerij - groene stroom & 595 & $-56 \%$ Z \\
\hline Grasdrogerij boerderij schaal - grijze stroom & 808 & $-40 \% \vee$ \\
\hline Grasdrogerij boerderijschaal - groene stroom & 528 & $-61 \%$ 乙 \\
\hline
\end{tabular}




\section{Discussie en conclusie}

In dit hoofdstuk presenteren we de belangrijkste effecten van kunstmatig grasdrogen en oplossingen voor de ontwikkeling van toekomstige grasdrogers op zonne-energie en kleine windmolens. Dit leidt tot conclusies van deze beoordeling met betrekking tot verschillende beslissingen die melkveehouders nemen om hun huidige voerbeheer, productie-efficiëntie te verbeteren in termen van energieefficiëntie en uiteindelijk de milieueffecten van hun product.

\subsection{Verliezen en Impact kunstmatige grasdroging op voerkwaliteit}

Op basis van de resultaten van verschillende eerdere werken, werd aangetoond dat het drogen van gras met een kunstmatige methode bijdraagt tot 10-15\% minder ds-verlies. In termen van het VEMgehalte leidt kunstmatig gedroogd gras tot 10-30\% minder verlies van VEM. Een efficiënte en snelle grasdroogmethode zou de flexibiliteit in het maaimoment ook bevorderen.

De verliezen die optreden bij het drogen van gras of klaver op het veld betreffen veelal bladmateriaal. Deze bladeren zijn verreweg het rijkste deel van de plant en het best verteerbaar. Aangezien het relatieve aandeel vezels toeneemt als gevolg van bovengenoemde verliezen, neemt de energie die nodig is voor de vertering toe ten opzichte van het verse gewas. Wanneer gras kunstmatig wordt gedroogd, vinden lagere verliezen plaats; daarom overtreft de waarde van gedroogd gras het hooi dat van gras wordt gemaakt op het veld.

Grasdroging zorgt voor een beter gebruik van het gras door het verhogen van het bestendige eiwit ten opzichte van graskuil. Het is nog onduidelijk of de toename van het bestendige eiwit ook leidt tot een toename van de opname van essentiële aminozuren in de darm.

De kwaliteit van het gemaaide gras bepaalt in sterke mate wat de voedingswaarde in de grasbrok zal zijn. Het behoud van de graskwaliteit is echter cruciaal bij verwerking voor opslag. Door het gedroogde gras te verwerken tot grasbrok kan het gebruikt worden als een 1 op 1 vervanger van krachtvoer, mits de voedingswaarde overeenkomt. Grasbrok geeft een hoger DVE en lager OEBgehalte dan bij hetzelfde product verwerkt tot graskuil. Bij substitutiepercentages van meer dan $50 \%$ krachtvoer naar grasbrok wordt minder opname verwacht. In het algemeen geldt dat hoe meer het rantsoen uit eigen gras bestaat, hoe belangrijker het DVE / OEB-rantsoen is; vooral omdat dit minder gecorrigeerd kan worden door middel van ingekocht voer zoals krachtvoer of maïskuilvoer. In de KringloopWijzer is voor de parameters conserveringsverliezen, DVE en OEB, geen onderscheid gemaakt tussen gedroogd gras en kuilgras. De KringloopWijzer is dus niet specifiek genoeg om de voordelen van gedroogd gras boven kuilgras te berekenen.

\subsection{Impact op $\mathrm{CO}_{2}$-footprint}

Op basis van de resultaten is de berekende gemiddelde $\mathrm{CO}_{2}$-footprint van grasbrok geproduceerd bij reguliere centrale droging (draaiend op kolen en grijze stroom) hoger dan bij reguliere krachtvoer (bijna 32\% hoger). Als de grasbrok geproduceerd wordt door middel van een geëlektrificeerde centrale grasdroger op groene stroom, dan zal de $\mathrm{CO}_{2}$-footprint lager zijn in vergelijking met krachtvoer en andere energiebronnen (grijze stroom en kolengestookte drogers).

Het drogen van gras op boerderijschaal leidt tot een substantiële reductie van de gemiddelde $\mathrm{CO}_{2}$ footprint ten opzichte van krachtvoer (40\%-61\%). Geëlektrificeerde grasdrogers dragen echter bij aan de vermindering van de $\mathrm{CO}_{2}$-footprint, terwijl drogers op groene stroom het meest bijdragen aan deze 
reductie. Het introduceren van grasdrogers die werken op een combinatie van grijze stroom en groene stroom zou een optie zijn.

\subsection{Uitdagingen voor toekomstige grasdrogers met zonne-elektriciteit}

In dit rapport hebben we gewezen op de hotspots van de ontwikkeling van grasdrogers op centrale of boerderijschaal die kunnen bijdragen aan de energietransitie in de landbouwsector en aan de netstabiliteit, voor het zover is, is er een drietal zaken die verder uitgewerkt moeten worden, te weten:

1. Op techniek gebaseerde uitdagingen:

- In het huidige rapport is een scenario met betrekking tot het drogen van gras op boerderijschaal op groene stroom (band- en trommeldrogers) ontworpen op basis van aannames, omdat dergelijke systemen nog niet op de markt zijn. Het is dus nog onduidelijk hoe elektrificatie het beste kan plaatsvinden, ook met het oog op maximale inzet op netstabiliteit.

- De methode van elektrificatie kan ook een effect hebben op de bruikbaarheid van de grasdroger voor netstabiliteit. De technologie welke uiteindelijk door individuele boeren of samenwerkende boeren of loonwerkers (die grasdrogen in hun dienstenpakket willen opnemen) wordt overgenomen, moet noodzakelijkerwijs voldoen aan de meest volledige economische en milieunormen.

2. Beheer en planning:

- Het drogen van gras moet vakkundig worden beheerd, zodat het energieverbruik in evenwicht is met de productie van groene stroom en de stabiliteit van het net als er groene stroom wordt geproduceerd. Droging en verwachte zonne-elektriciteit opbrengst dienen afgestemd te worden op elkaar.

- Het drogen van gras moet goed worden beheerd in relatie tot andere activiteiten op de boerderij, zoals maaitijd, bemesting, voersamenstelling en voermanagement. Dit is van belang wanneer al deze activiteiten moeten voldoen aan de overproductie van elektriciteit tijdens piekuren. De ontwikkeling van maairobots (zoals de Lely Exos) maakt het mogelijk om dagelijks vers gras te maaien en aan te bieden aan een band- of trommeldroger. Er is een direct effect op de keuze van het geschikte mechanisme voor het drogen van gras (d.w.z. energietechnologie, gecentraliseerd of gedecentraliseerd, enz.).

3. Voerkwaliteit:

- Er is nu vooral informatie beschikbaar over de voerkwaliteit van gras dat gedroogd is bij centrale drooginstallaties. Drogers op boerderijschaal zijn net in opkomst en moeten verder worden bestudeerd in termen van het type product gedroogd gras (gedroogd gras in pellets of balen).

- Hoogwaardig gras kan krachtvoer vervangen. Het is echter nog niet duidelijk wat de gewenste kwaliteit is en hoe dit in ieder geval met kunstmatige grasdrogers kan worden bereikt. 


\section{Literatuur}

Boxem, T., 1992. Vervanging krachtvoer door grasbrok of voederbieten. Praktijkonderzoek/Praktijkonderzoek Rundvee, Schapen en Paarden (PR), Waiboerhoeve 5(6), 11-15.

Boxem, T., 1993. Veevoedkundige waarde gras-en luzernebrok. Proefstation voor de Rundveehouderij, Schapenhouderij enPaardenhouderij.

Brammer, J., Bridgwater, A., 1999. Drying technologies for an integrated gasification bio-energy plant. Renewable and sustainable energy reviews 3(4), 243-289.

den Boer, D., Bakker, R., 2006. Bemesting en kwaliteit graskuil: Koeien \& Kansen, 1997-2003. Animal Sciences Group.

Dutch Dryers BV., https://www.dutchdryers.com/pages/home.php?lang=EN (laatst bezocht: september 2021).

García-Valladares, O., Ortiz, N., Pilatowsky, I., Menchaca, A., 2020. Solar thermal drying plant for agricultural products. Part 1: Direct air heating system. Renewable Energy 148, 1302-1320.

Jannasch, R., Quan, Y., Samson, R., 2001. A process and energy analysis of pelletizing switchgrass. Final Report, Resource Efficient Agricultural Production (REAPCanada), Ste. Anne de Bellevue.

Klop, A., ter Veer, D., Henniphof, C., Koopman, W., Plomp, M., van Duinkerken, G., 2004. Benutting najaarssnede grasklaver in biologische melkveerantsoenen= Utilization of autumn cut grassclover in organic dairy cow rations. Animal Sciences Group.

Lasco Co., https://www.lasco.at/rundballentrocknung/ (laatst bezocht: september 2021).

Loman, N.N., 2012. Groener drogen.

Mani, S., Sokhansanj, S., Bi, X., Turhollow, A., 2006. Economics of producing fuel pellets from biomass. Applied Engineering in agriculture 22(3), 421-426.

melkvee.nl, https://www.melkvee.nl/artikel/45635-hooi-maken-in-houtsnipper-oven/ (laatst bezocht: september 2021).

Nieuweoogst, 2019. Drying grass is on the rise in the Netherlands. https://www.nieuweoogst.nl/nieuws/2019/03/09/gras-drogen-is-in-opkomst-in-nederland (laatst bezocht: september 2021).

Parke, D., Dumont, A., Boyce, D., 1978. A mathematical model to study forage conservation methods. Grass and Forage Science 33(4), 261-273.

Philipsen, A., Meerkerk, B., van Noord, T., Verhoeff, T., 2020. Eiwit van eigen land: Brochure.

Remmelink, G., van Middelkoop, J., Ouweltjes, W., Wemmenhove, H., 2019. Handboek melkveehouderij 2019/20. Wageningen Livestock Research.

Roos, C.J., 2008. Biomass drying and dewatering for clean heat \& power. Northwest CHP Application Center Olympia (WA).

Rotz, C., 2003. Effectiveness of Equipment to Speed Hay Drying, Pennsylvania Grazing and Forage Conference Proceedings. pp. 17-22.

Rudnick \& Enners, . https://www.rudnick-enners.com/en/products/drying/belt-dryer/index.html, laatst bezocht: september 2021.

Toft, A.J., 1998. A comparison of integrated biomass to electricity systems.

Visser, A., Bos, B., Gollenbeek, L., Migchels, G., Stortelder, J., Veefkind, W., van der Voort, M., 2020. Zonder netverzwaring maximaal hernieuwbare energie produceren: Ontwerpen voor melkveehouderij en akkerbouw om meer hernieuwbare energie te produceren door energieproductie op het eigen bedrijf flexibel te benutten. Stichting Wageningen Research, Wageningen Plant Research.

Wernet, G., Bauer, C., Steubing, B., Reinhard, J., Moreno-Ruiz, E., Weidema, B., 2016. The ecoinvent database version 3 (part I): overview and methodology. The International Journal of Life Cycle Assessment 21(9), 1218-1230.

Wilkins, R., 1976. The potential for increased use of ensiled crops for animal production with particular reference to support energy inputs, Improving the Nutritional Efficiency of Beef production. Commission of the European Communities, Luxembourg.

Yáñez-Ruiz, D.R., Morgavi, D., T. Misselbrook, T., Melle, M., Dreijere, S., Aes, O., Sekowski, M., 2017. Reducing livestock emissions from Cattle farming- Feeding strategies to reduce methane and ammonia emissions. EIPAGRI Focus Group. 


\section{Bijlage 1 Aannames voor het berekenen van $\mathrm{CO}_{2}$-footprint}

Tabel 1 Aannames voor grasdrogen

\begin{tabular}{lll}
\hline Parameter & Eenheid & Waarde \\
\hline MJ van olie & $\mathrm{kg} \mathrm{DM} / \mathrm{ha} / \mathrm{cut}$ & 3000 \\
\hline kWh uit elektriciteit & $\mathrm{MJ} / \mathrm{kg}$ verdampt water & 3,5 \\
\hline Elektriciteit- Malen & $\mathrm{kWh} / \mathrm{kg}$ evaporated water & 0.05 \\
\hline Gas- Malen & $\mathrm{MJ} / 1000 \mathrm{~kg}$ & 273 \\
\hline Elektriciteit-Pellet & $\mathrm{MJ} / 1000 \mathrm{~kg}$ & 116 \\
\hline Gas-Pellet & $\mathrm{MJ} / 1000 \mathrm{~kg}$ & 315 \\
\hline Rendement warmtepomp - & $\mathrm{MJ} / 1000 \mathrm{~kg}$ & 135 \\
hoogwaardigewarmte & $\%$ & 70 \\
\hline Rendement warmtepomp - & $\%$ & 500 \\
\hline laagwaardigewarmte & $\mathrm{Ldiesel/ha}$ & 1 \\
\hline Voordrogen op het veld & $\mathrm{km}$ & 50 \\
\hline Transport uitgaand: centrale grasdroger & $\mathrm{km}$ & 5 \\
\hline Inkomend transport: boerderijschaal & $\mathrm{km}$ & 1 \\
\hline Uitgaand transport: boerderijschaal & & \\
\hline
\end{tabular}

Tabel 2 Emissiefactoren om $\mathrm{CO}_{2}$-footprint te berekenen (Bron: Ecoinvent).

\begin{tabular}{lll} 
Parameter & Eenheid & Waarde \\
$\mathrm{CO}_{2}$-waard diesel & $\mathrm{g} \mathrm{CO}_{2 \mathrm{eq}} /$ litre diesel & 3254 \\
\hline $\mathrm{CO}_{2}$-waard kolen & $\mathrm{g} \mathrm{CO}_{2 \text { eq }} / \mathrm{MJ}$ coal & 134,6 \\
\hline $\mathrm{CO}_{2}$-waard elektriciteit & $\mathrm{g} \mathrm{CO}_{2 \mathrm{eq}} / \mathrm{MJ}$ electricity $\mathrm{NL}$ & 201,9 \\
\hline $\mathrm{CO}_{2}$-waard groene stroom & $\mathrm{g} \mathrm{CO}_{2 \mathrm{eq}} / \mathrm{kWh}$ electricity green NL & 4,34 \\
\hline $\mathrm{CO}_{2}$-waard transport vrachtauto & $\mathrm{g} \mathrm{CO}_{2 \mathrm{eq}} /$ ton.km & 101 \\
\hline $\mathrm{CO}_{2}$-waard gas & $\mathrm{g} \mathrm{CO}_{2 \mathrm{eq}} / \mathrm{MJ}$ gas & 68 \\
\hline GWP methaan & $(-)$ & 34 \\
\hline
\end{tabular}




\section{Bijlage 2 Resultaten van $\mathrm{CO}_{2}$-footprint}

Scenario 1: Centrale grasdrogerijschaal

Variant 1: Regulier kolengestookt en grijze stroom

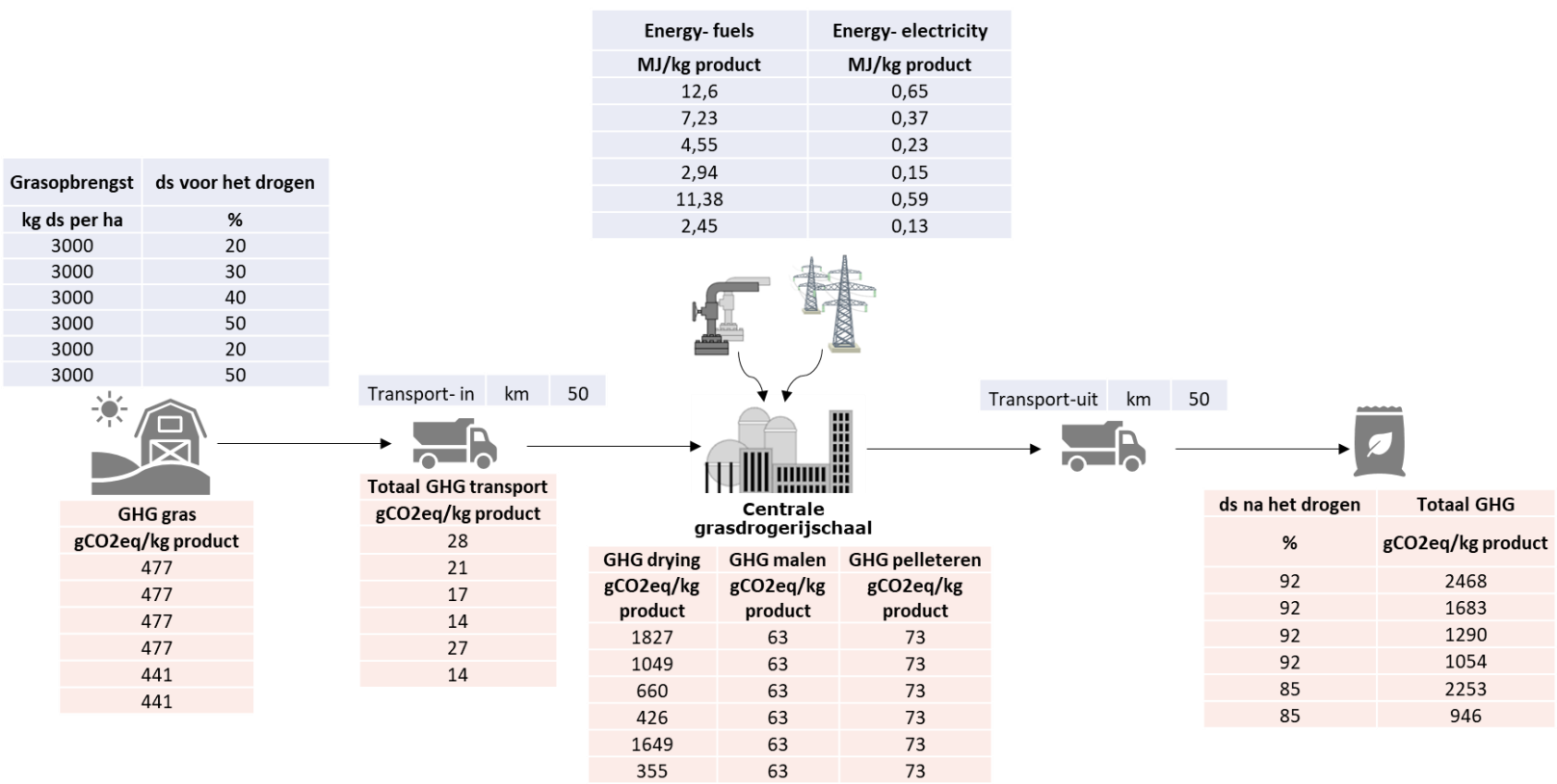


Scenario 1: Centrale grasdrogerijschaal

Variant 2: Regulier kolengestookt en groene stroom

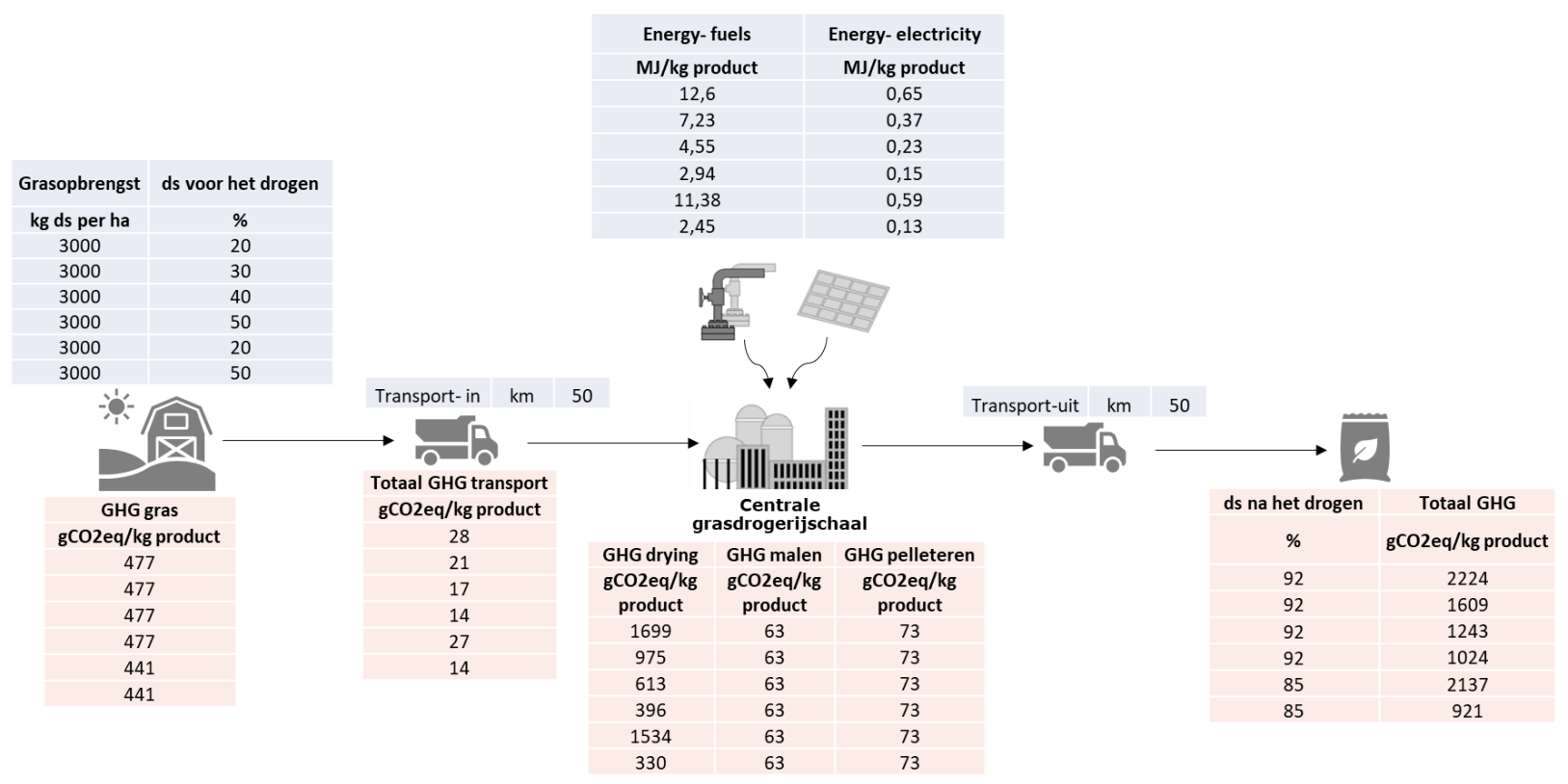


Scenario 1: Centrale grasdrogerijschaal

Variant 3: Elektrificatie met grijze stroom

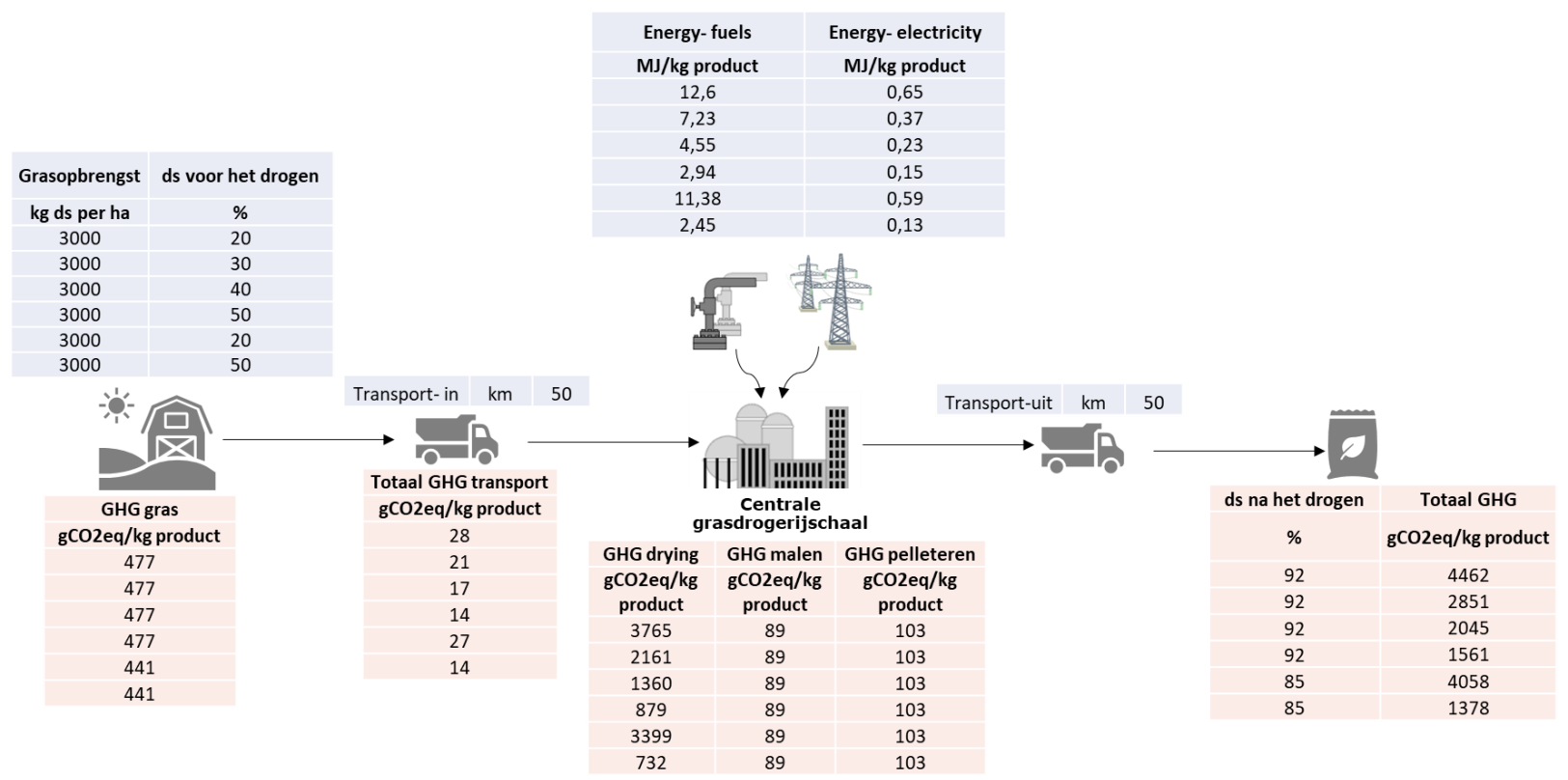


Scenario 1: Centrale grasdrogerijschaal

Variant 4: Elektrificatie met groene stroom

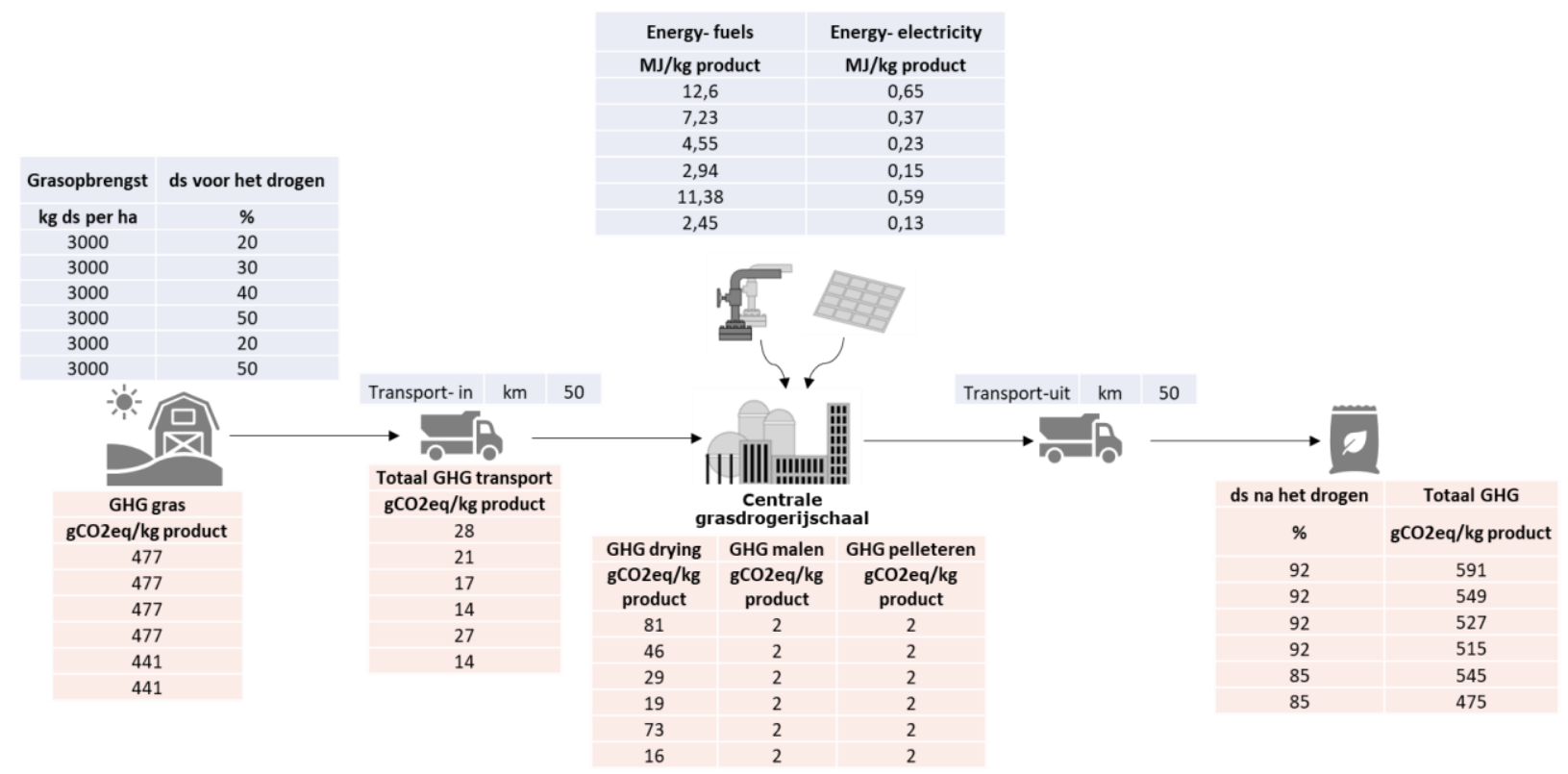


Scenario 2.a: Grasdroging op boerderijschaal met voordrogen en laagwaardige warmte Variant 1: Elektrificatie met grijze stroom

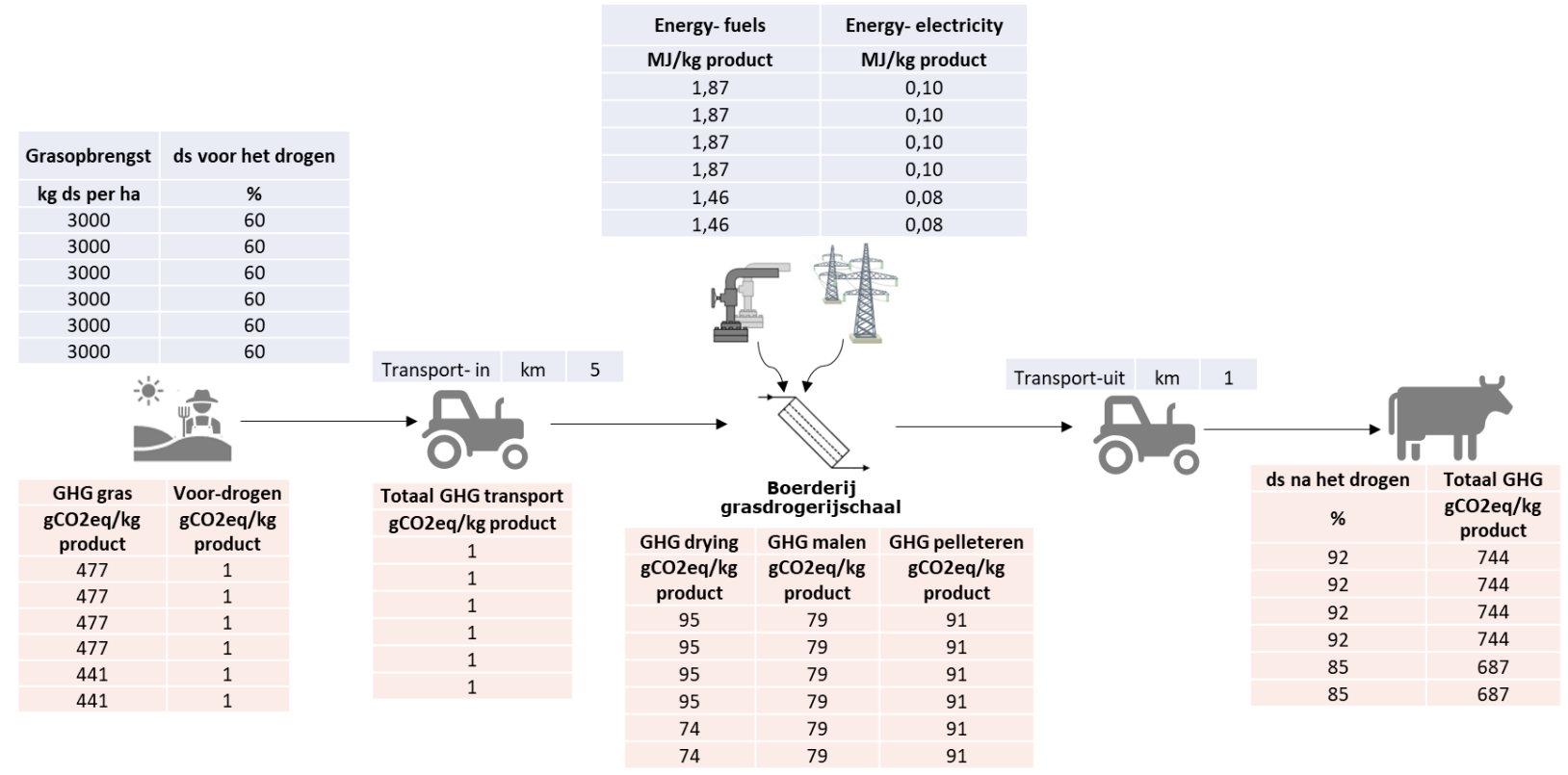


Scenario 2.a: Grasdroging op boerderijschaal en met voordrogen en laagwaardige warmte Variant 2: Elektrificatie met groene stroom

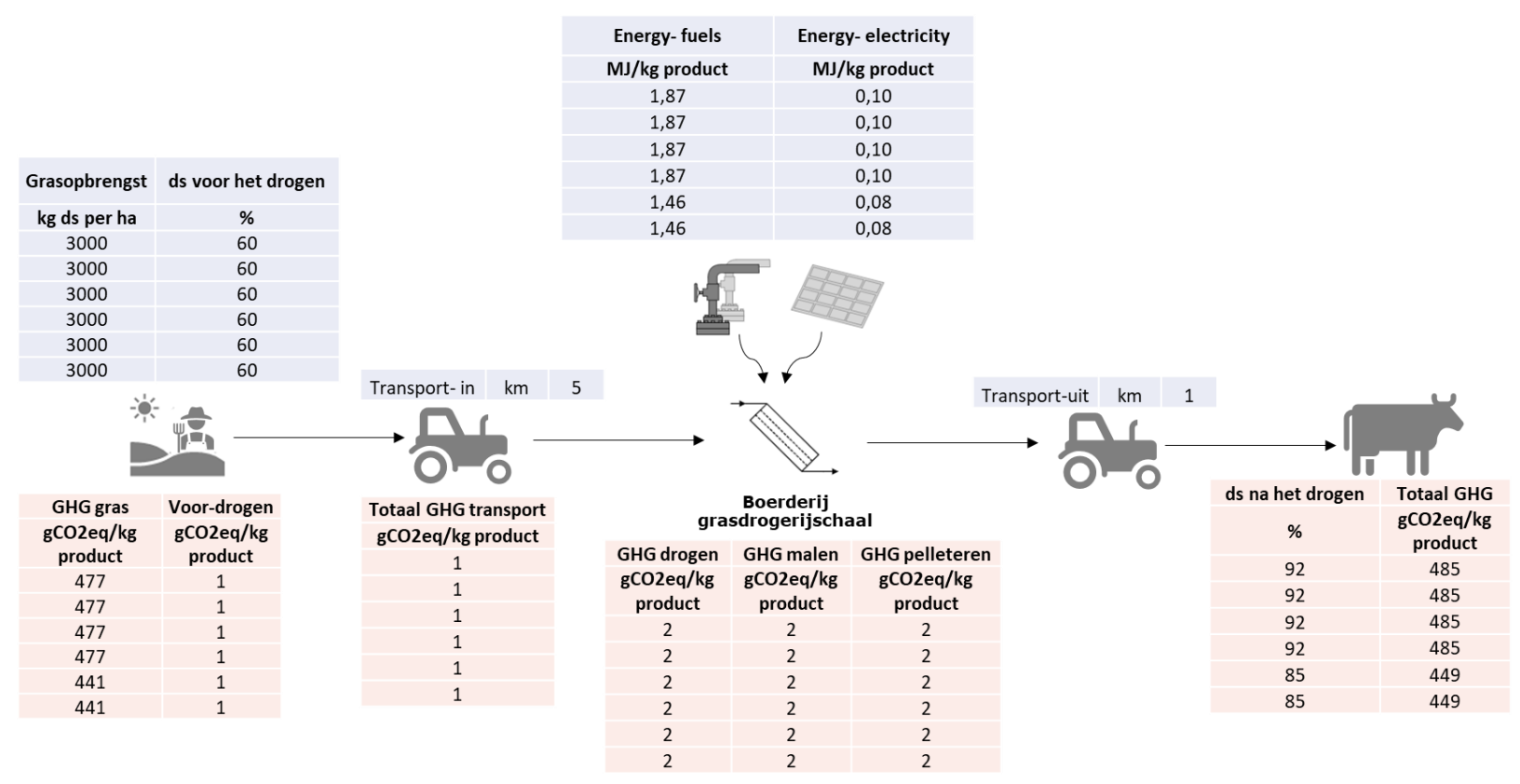


Scenario 2.a: Grasdroging op boerderijschaal, zonder voordrogen en met laagwaardige warmte Variant 3: Elektrificatie met grijze stroom

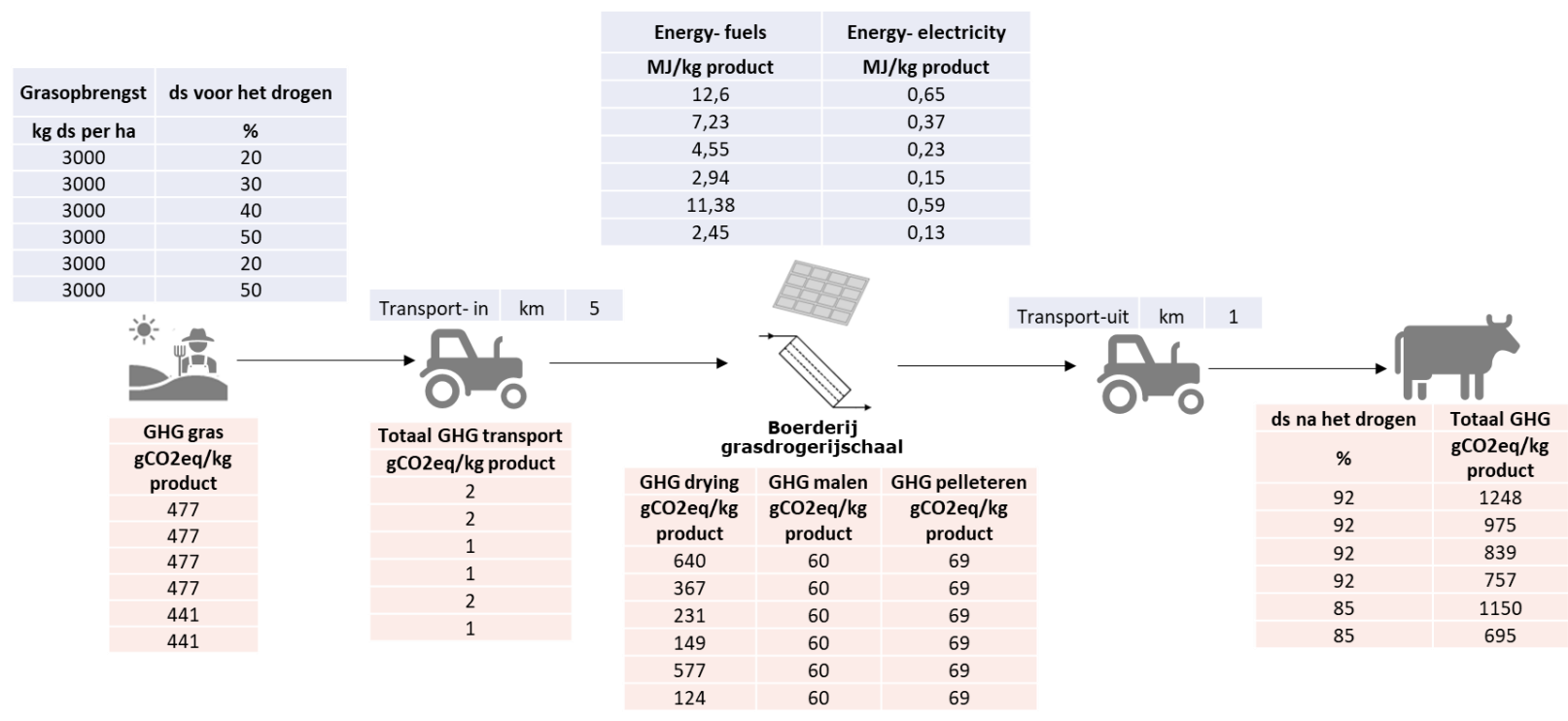


Scenario 2.a: Grasdroging op boerderijschaal, zonder voordrogen en met laagwaardige warmte Variant 4: Elektrificatie met groene stroom

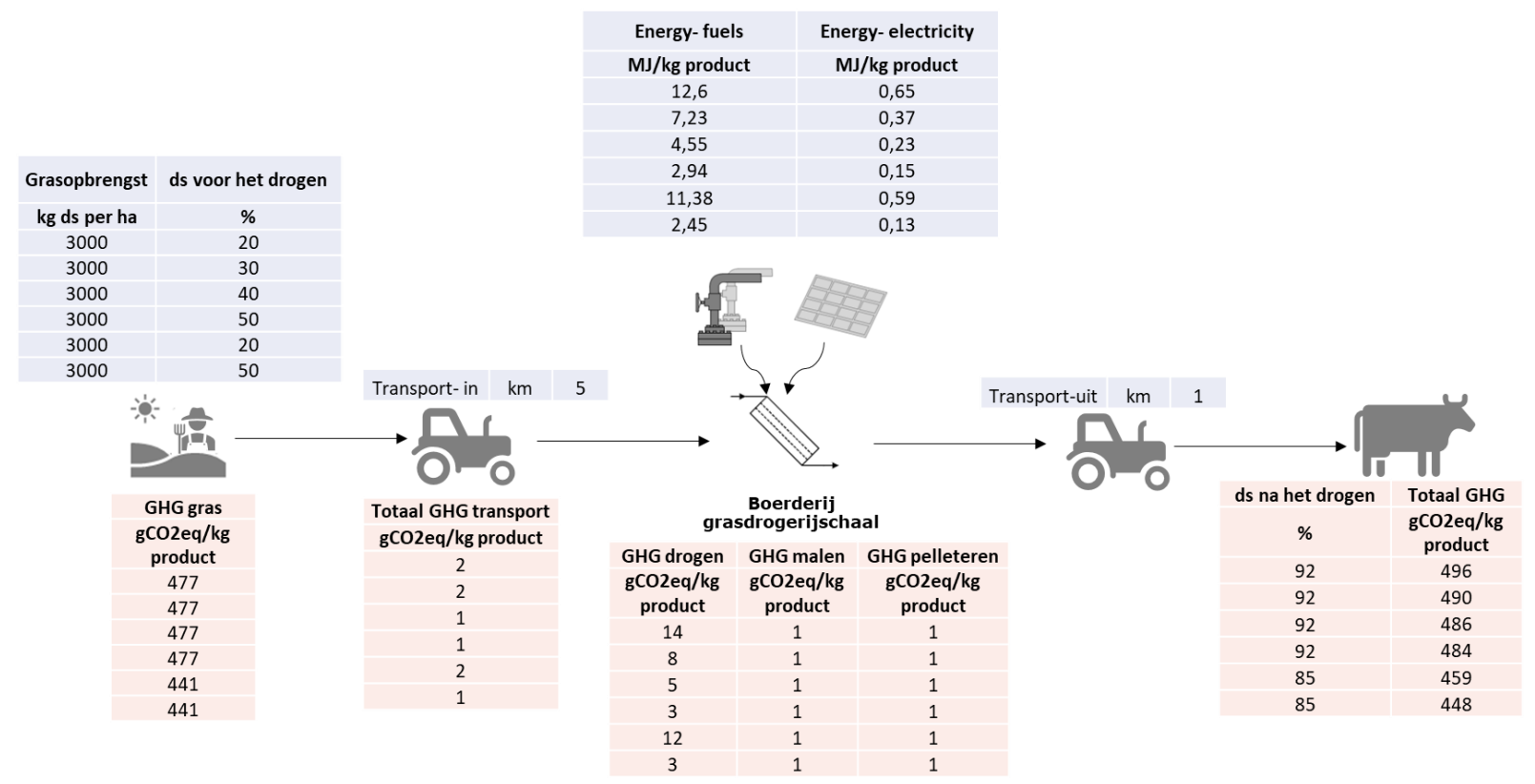


Scenario 2.b: Grasdroging op boerderijschaal met voordrogen en hoogwaardige warmte Variant 1: Elektrificatie met grijze stroom

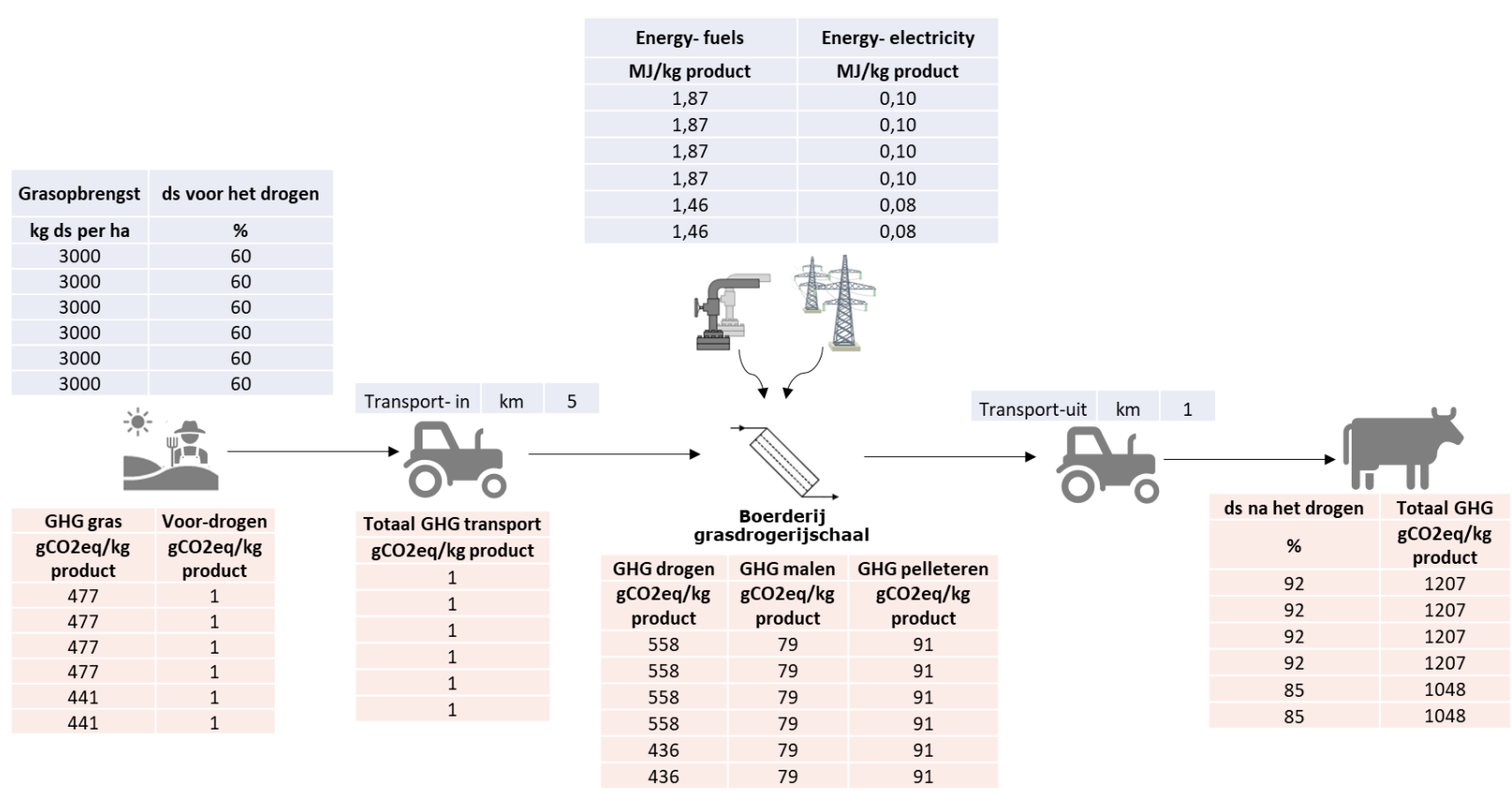


Scenario 2.b: Grasdroging op boerderijschaal en met voordrogen en hoogwaardige warmte Variant 2: Elektrificatie met groene stroom

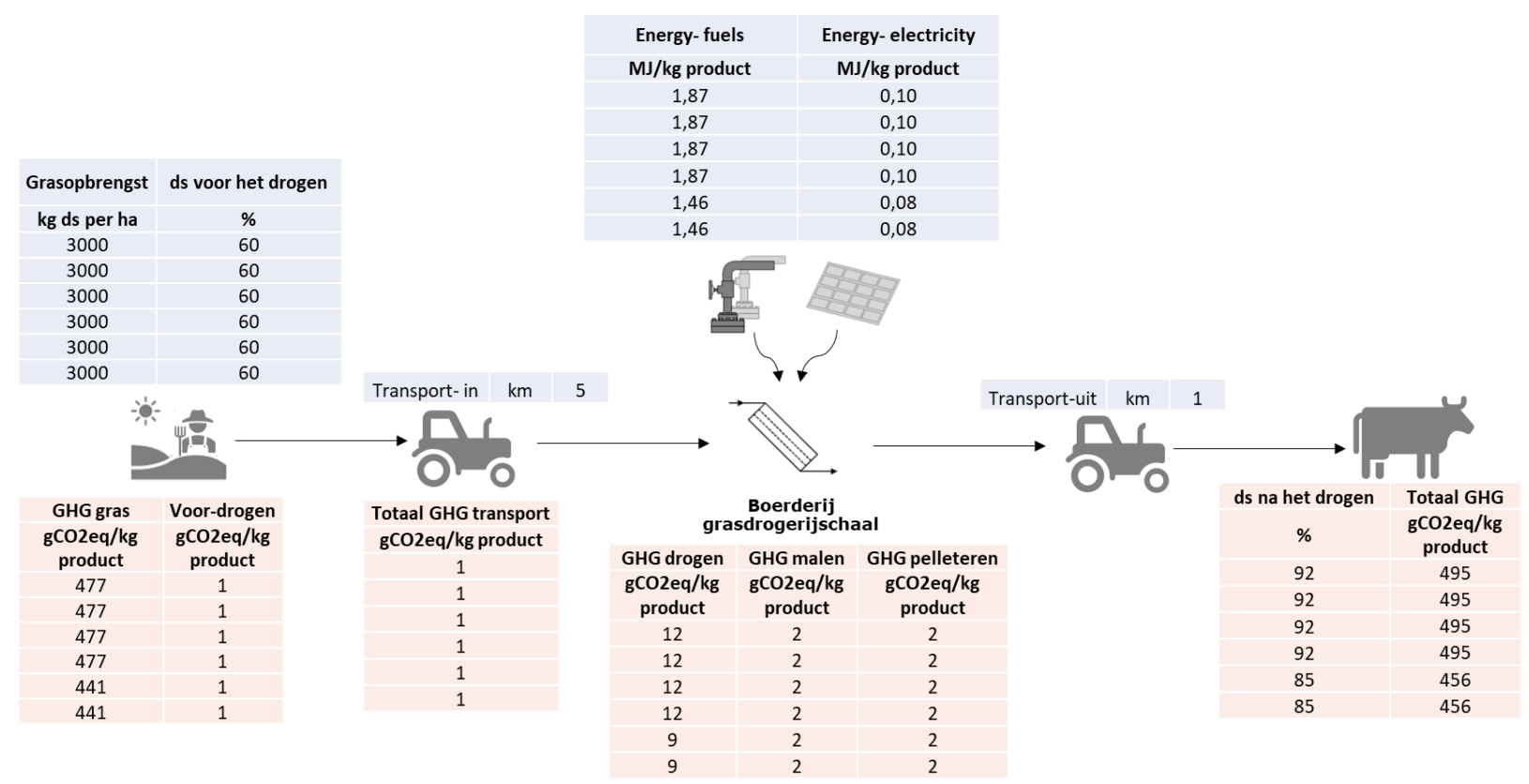


Scenario 2: Grasdroging op boerderijschaal, zonder voordrogen en hoogwaardige warmte Variant 3: Elektrificatie met grijze stroom

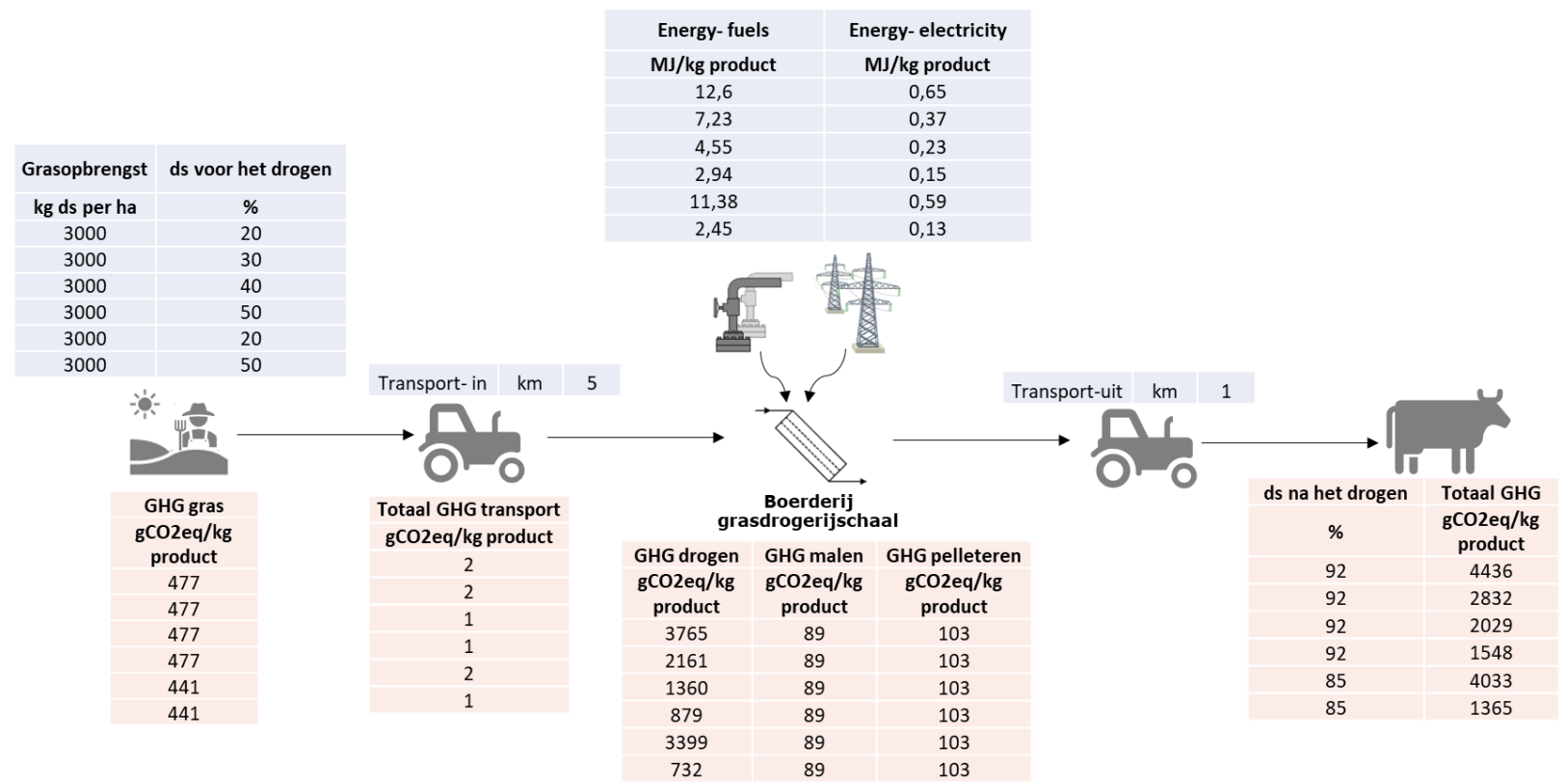


Scenario 2: Grasdroging op boerderijschaal, zonder voordrogen en met hoogwaardige warmte Variant 4: Elektrificatie met groene stroom

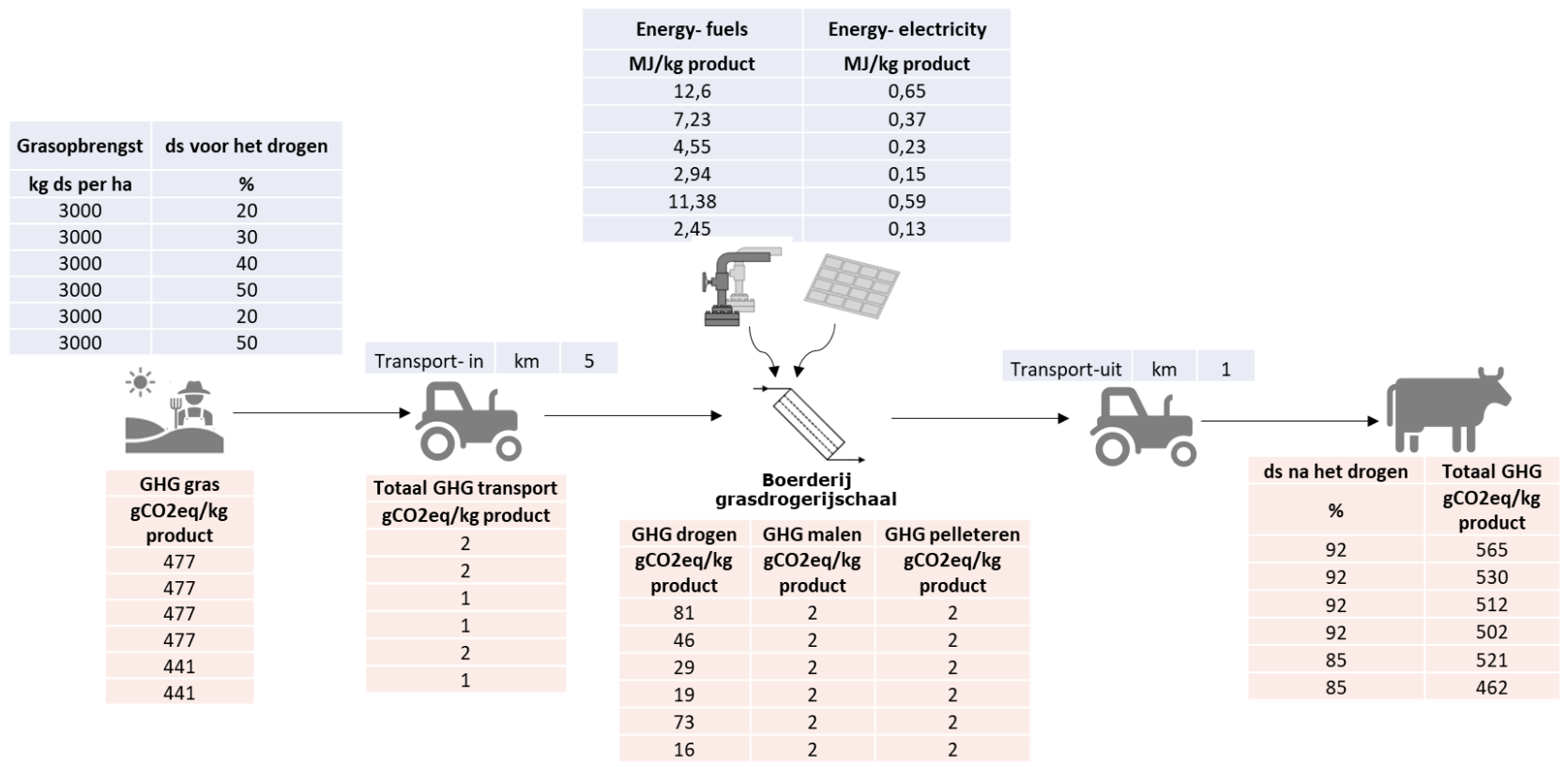




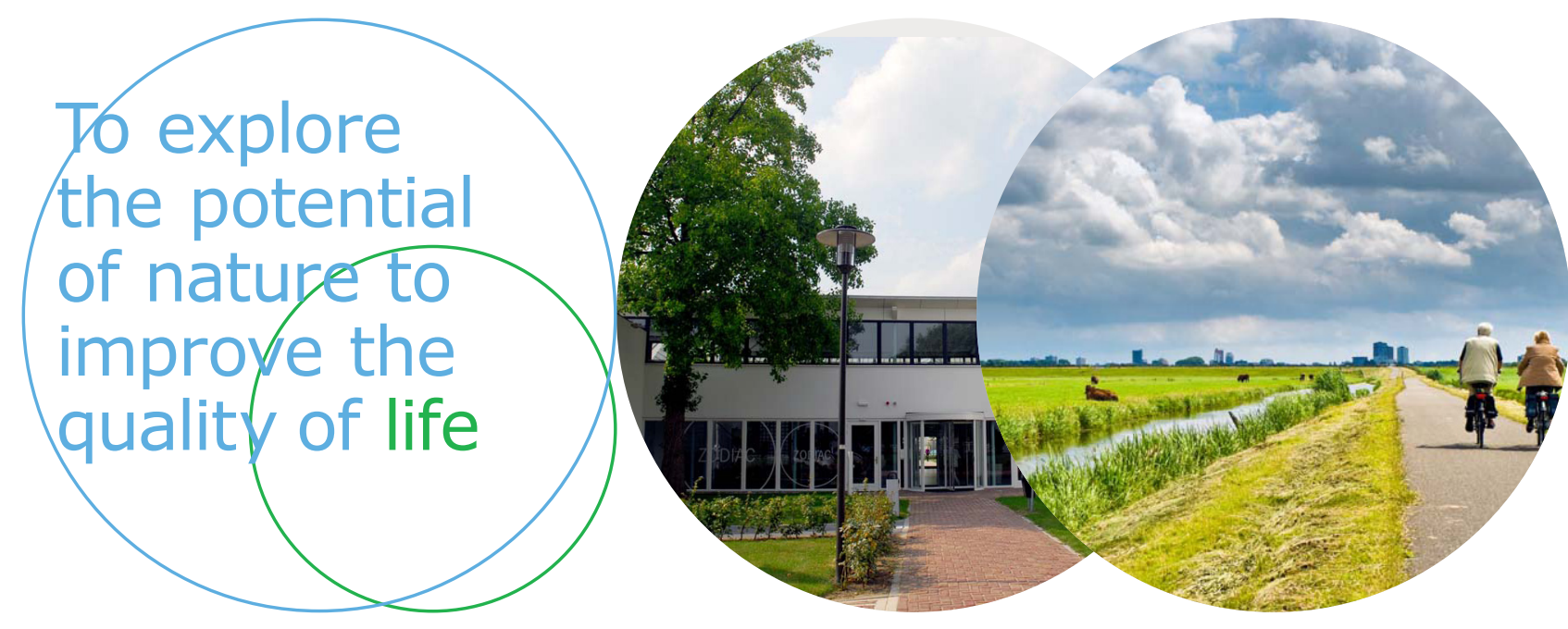

Wageningen Livestock Research Postbus 338

$6700 \mathrm{AH}$ Wageningen

T 0317483953

E info.livestockresearch@wur.nl www.wur.nl/livestock-research
Wageningen Livestock Research ontwikkelt kennis voor een zorgvuldige en renderende veehouderij, vertaalt deze naar praktijkgerichte oplossingen en innovaties, en zorgt voor doorstroming van deze kennis. Onze wetenschappelijke kennis op het gebied van veehouderijsystemen en van voeding, genetica, welzijn en milieu-impact van landbouwhuisdieren integreren we, samen met onze klanten, tot veehouderijconcepten voor de $21 \mathrm{e}$ eeuw.

De missie van Wageningen University \& Research is 'To explore the potential of nature to improve the quality of life'. Binnen Wageningen University \& Research bundelen 9 gespecialiseerde onderzoeksinstituten van Stichting Wageningen Research en Wageningen University hun krachten om bij te dragen aan de oplossing van belangrijke vragen in het domein van gezonde voeding en leefomgeving. Met ongeveer 30 vestigingen, 6.500 medewerkers en 10.000 studenten behoort Wageningen University \& Research wereldwijd tot de aansprekende kennisinstellingen binnen haar domein. De integrale benadering van de vraagstukken en de samenwerking tussen verschillende disciplines vormen het hart van de unieke Wageningen aanpak. 